Estonian Journal of Archaeology, 2005, 9, 2, 93-131

\title{
Marika Mägi
}

\section{MORTUARY HOUSES IN IRON AGE ESTONIA}

This article presents a new attempt at reconstructing Estonian tarand-graves. Archaeological investigations carried out in Saaremaa (Ösel) during the past ten years have indicated that by the Migration Era (450-600 AD), corner-joined log structures partly resting on stone foundations were being built there as mortuary houses; remains of Pre-Roman Iron Age $(500 \mathrm{BC}-50 \mathrm{AD})$ cult houses have been found as well. The article discusses the possibility that Roman Iron Age (50-450 AD) tarand-graves may also have actually been log constructions on stone foundations. The excavated tarand-graves of Coastal Estonia are being compared with ethnographic buildings and archaeological construction remains, as well as the cult- and/or mortuary houses from elsewhere.

Artiklis on esitatud Eesti tarandkalmete uus rekonstruktsioonikatse. Viimase kümne aasta jooksul toimunud arheoloogilised kaevamised Saaremaal on osutanud, et hiljemalt rahvasterännuajal (450-600 $\mathrm{AD}$ ) leidus siin ristpalkidest, osalt kivivundamendile tuginevaid matusehooneid. Ka on leitud eelrooma rauaaegsete (500 BC - $50 \mathrm{AD})$, ilmselt samuti osalt puidust kultushoonete jäänuseid. On arutletud võimaluse üle, et ka rooma rauaaega (50-450 AD) kuuluvad tarandkalmed on võinud olla kivivundamendil puithooned. Ranniku-Eestis seni kaevatud tarandkalmeid on sel eesmärgil võrreldud nii etnograafiliste hoonete kui ka arheoloogiliste ehitusjäänustega, samuti sarnaste kultus- ja/või surnumajadega teistes maades.

Marika Mägi, Institute of History, Tallinn University, Rüütli 6, 10130 Tallinn, Estonia; Marika.Magi@mail.ee

The notion that man-made cult houses have not been characteristic of ancient Estonians dates back so long that it has developed into an axiom. The existence of artificial cult sites has been denied just as unanimously, irrespective of related evidence from the neighbouring countries (see, e.g., Šturms 1938; Daugudis 1995; Graudonis 1997; Kaliff 1997; Victor 2002). The forebears of current Estonians are supposed to have worshipped sacred trees and groves, stones and springs; in line with the nature-sensitive character of proper Finno-Ugrians, they implemented sacred rites in the great outdoors, mostly at holy places in extraordinary natural surroundings, with the traditions handed down from generation to generation (e.g. Lang 1999; Vedru 2004). 
Without doubting the existence of sacred places in the local landscape, it should nevertheless be stated that the stance denying the possibility of cult structures rises from the long tradition of trying to reconstruct Estonian prehistoric religion mainly on the basis of 19th century folklore (e.g. Mets 2003; Jonuks 2005). 13 th century chronicles do not mention Estonian cult houses either, talking merely of sacred groves and the wooden idols erected there. Regrettably, 13th century sources do not aid in making assumptions on Migration Period worship practices, let alone earlier beliefs and rituals. Lately, several researchers have pointed out the occurrence of critical turns in prehistoric religion, in the course of which the concept of the afterlife could have changed considerably (see Jonuks 2003; Mägi 2005). In short, there is no other evidence to support either the existence or absence of Iron Age cult structures apart from archaeological sources.

Archaeological evidence, alas, can be interpreted in a multitude of ways, especially in the case of remains related to rituals. For a long period, archaeologists home and abroad have deemed it unscholarly to attribute cultic functions to any find - the attitude being fully reflected by the inside joke that speaks of all objects of obscure function being branded as "sacred". In more recent times, however, the ice has started to thaw and there have been some novel attempts at interpreting the sacred aspects of landscape, for example (e.g. Lang 1999; Vedru 2004).

The importance of prehistoric stone graves as cult sites has been expressed both in the writings of Valter Lang and the author of the current article (MägiLõugas 1997; Lang 1999). So far, however, only one Bronze Age or Pre-Roman Iron Age structure interpreted as cult house remains has been excavated in Estonia - it is the remains of what will likely appear to have been a horizontal log construction built on a stone foundation at Tõnija, on Saaremaa Island (Mägi 2001; Mägi \& Mägi 2002). There are also other structures with massive stone walls dating to the Pre-Roman Iron Age in Saaremaa (at Kaali, Võhma and Pidula) that can be interpreted as cultic rather than profane constructions.

The current article will not, however, concentrate on the subject of sacral buildings mentioned above, but rather deliberate on the theme of stone graves as cult sites and as mortuary houses in the direct meaning of the term. Due to lack of space, the ideological background of the constructions will not be analysed here; instead, the article will focus on conveying the structural characteristics of the remains. All of the burial places that are discussed below have previously been classified as tarandgraves. The article examines single tarand-graves and regular-shaped tarand-graves ${ }^{1}$

1 The term regular-shaped tarand-graves goes for multi-tarand graves, also called typical tarandgraves (e.g. Lang 1996, 298, 320-322), in which the tarands are presented in regular rectangular layout, are more or less of the same length and attached to each other along the longer walls. The tarands in these graves are normally bigger than what is typical for early tarand-graves. In Saaremaa at least, the walls of the regular-shaped tarand-graves have originally been about $50 \mathrm{~cm}$ high while early tarand-graves had been much flatter constructions (see also Mägi 2005). The differences in the wall structure and the internal constructions of these two grave types nevertheless remain obscure due to limited attention to detail in - or a total absence of - earlier excavation reports. 


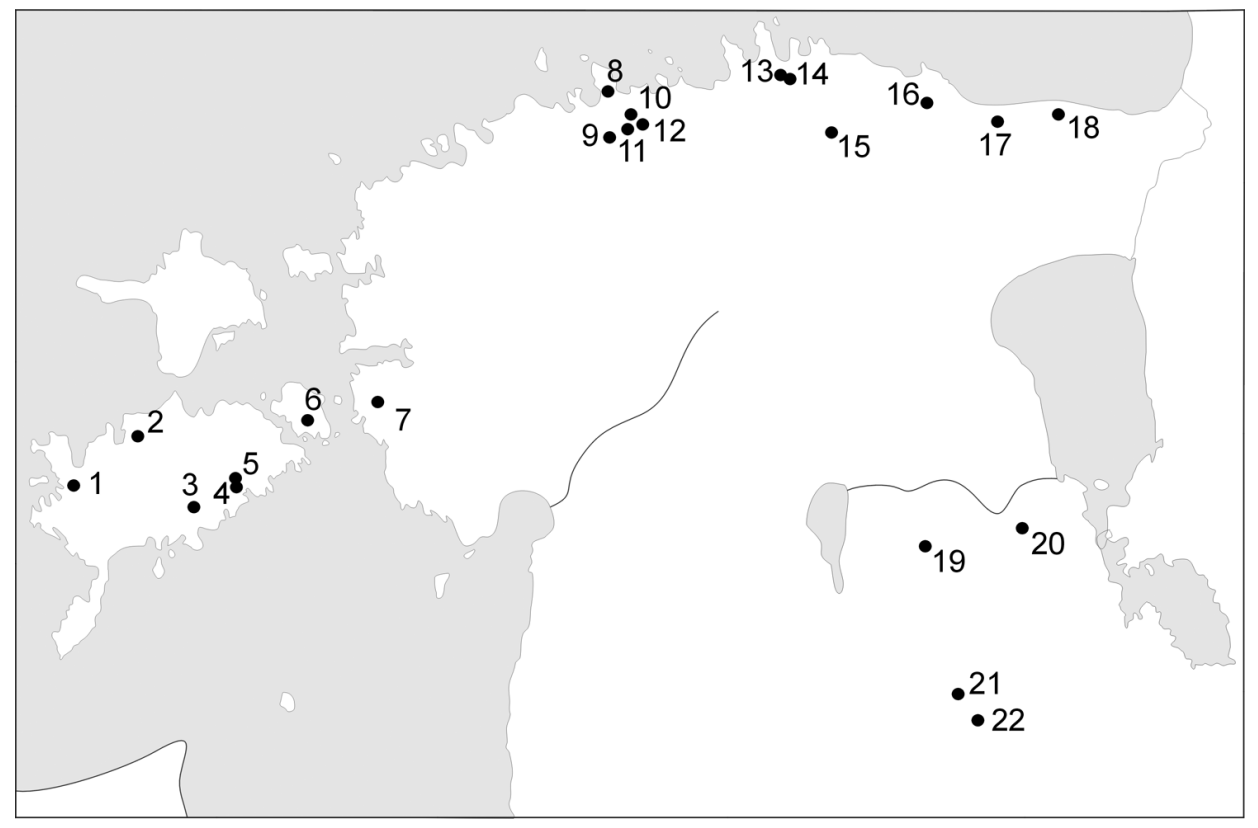

Fig. 1. Graves mentioned in the text. 1 Paju, 2 Võhma, 3 Liiva-Putla, 4 Lepna, 5 Tõnija, 6 Mäla, 7 Kõmsi, 8 Viimsi, 9 Lehmja-Loo, 10 Proosa, 11 Lagedi, 12 Saha, 13 Tõugu, 14 Uusküla, 15 Ojaveski, 16 Pada, 17 Jäbara, 18 Toila, 19 Jaagupi, 20 Mäletjärve, 21 Virunuka, 22 Sadrametsa.

Joon 1. Tekstis mainitud kalmed.

from Coastal Estonia (Fig. 1) ${ }^{2}$, most of which date back to the 2nd-7th centuries $\mathrm{AD}$, though a few have also been dated to the Pre-Roman Iron Age. ${ }^{3}$

Although the abundant source material from the tarand-graves of Inland Estonia has not been analysed in detail for the purposes of this paper, it is quite probable that the arguments presented here could also apply to those. However,

2 The author believes that in the analyses of Estonian archaeological data, two larger cultural zones should be distinguished that do not yield entirely analogous archaeological (nor linguistic or ethnographic) material. Several previous researchers have also indicated the existence of separate cultural areas (see Vassar 1966; Lõugas 1972; Lang 1987), though the differences have rarely been considered in material culture analyses. I have preferred to name these regions Coastal and Inland Estonia. Obviously, the distinction does not exclude the presence of lesser cultural variations (sub-regions), nor of some similarities between the two prevalent regions. In addition, some transitional areas can be discerned (e.g. Virumaa), which display the characteristics of both Coastal and Inland Estonia (see also Mägi 2005).

3 For lack of space, it will be impossible to ponder here on the question of dating the tarandgraves; hopefully, that should not have any considerable effect on the presented vision of the construction of graves and/or mortuary houses. It should nevertheless be noted that a small group of single tarand-graves as well as some regular tarand-graves (e.g. Tõugu II B, Uusküla II, Poanse II) have been dated to the late Pre-Roman Iron Age (e.g. Lang 2000, 147-161; Mandel 2000). 
certain structural peculiarities of Coastal Estonian graves, complemented with differences in funerary customs (for example, in contrast with the Coastal Estonian graves, the dominant burial type in Inland Estonian tarand-graves appears to have been cremation; see Laul 2001, 189-197) indicate the possibility that the tradition of mortuary houses may have existed only in the coastal areas.

It should also be pointed out that the following discussion does not include the so-called early tarand-graves characteristic of Coastal Estonia, which have mainly been dated to the Pre-Roman Iron Age. Various differences in the structure and burial type of the early tarand-graves have given the author reason to doubt their direct kinship with the so-called classical tarand-graves, especially in the case of irregular enclosure graves that should be classified as an entirely separate subtype (Mägi 2005; in print, a). The latter were mainly prevalent in Saaremaa and northwestern Estonia and it is quite likely that it was common to have a separate cult house situated right beside such graves (the examples being Tõnija and possibly also Mäla).

\section{Interpretations of tarand-graves}

In the 19th century, Estonian tarand-graves were interpreted as Gothic boatgraves. Owing to the then excavation methods and paradigmatic prejudice, the graves were seen as pointed oval "boats", with the horizontal stone rows representing the "thwarts". When the "Gothic boat-grave" theory was finally refuted in the 1880s and it was proved that the graves mainly consisted of rectangular enclosures, the term stone row graves (kiviridakalmed in Estonian and Steinreihengräber in German) remained in use for a long time. In the late 19th century Pavel Viskovatov came up with the idea of family graves, with every new generation of the patriline attaching a new tarand to the previous one(s), thus creating burial grounds of tarand-grave chains (Tvauri 2003). With some alterations, Viskovatov's hypothesis has persevered to the present day (see Шмидехельм 1955, 190-191; Lang 1999, 76-77; 2000, 212-213).

In the 1930s, Harri Moora started to use the expression tarand-grave (where 'tarand' is an Estonian word for 'enclosure'), which has remained the accepted term for the grave type and also been adopted by other languages. An important contribution to the research of tarand-graves was made by Artur Vassar in his manuscript thesis, in which he analysed tarand-graves as symbolic mortuary houses. Vassar pictured the graves as having looked like irregularly shaped stone mounds, for he believed that stones had been added to the tarands with every new burial, with the stone layers eventually brimming over the tarand walls, covering them completely and subsequently forming a structural rim of debris close around the grave (Vassar 1943, 295-296, $317 \mathrm{ff}$ ).

It can be said that the similarity between dwelling foundations and the walls of classic tarand-graves has been evident already to earlier researchers. Seeing 
the grave sites merely as symbolic houses was conditioned by a long research tradition and probably also by inadequate knowledge of prehistoric building remains. In fact, it could be stated that up till the 1990s, the treatment of ancient burial customs in Estonian archaeological scholarship proceeded from the Christian, or modern, idea of "what a funeral should be like". The idea that what constituted a proper funeral a thousand years back could be entirely different from the present started to gain ground only at the very end of the 20th century. The image of erratic sets of ancestral bones being brought into a horizontal log construction evidently had not really comported with the idea of a "proper ancient funeral".

Valter Lang, who discusses the irregularly shaped (early) tarand-graves as an earlier stage in the evolution of classical tarand-graves, has explained the quadrangular shape of the tarand-grave as a symbolic manifestation of Celtic or Baltic field systems (Lang 1999, 78-79; 2000, 212). This assumption may be appropriate for interpreting early tarand-graves, but in the case of regular-shaped tarand-graves or single tarands, it appears much less convincing. Lang's argument that it would be difficult to imagine the joined enclosures of the classical tarandgrave standing for a roofed structure (Lang 1999, 79) is not valid in the light of ethnographic evidence (see below). It is quite possible that equating regular-shaped tarand-graves with Pre-Roman Iron Age early tarand-graves may be one of the reasons why the similarity between regularly-shaped tarand-graves, archaeological house remains, and ethnographic buildings has been overlooked. Early tarandgraves do not suggest likeness to houses in horizontal log technique, mainly because of being too small or too irregularly shaped, and if that grave type was indeed directly connected with the classical tarand-graves, the latter could not have been mortuary houses either.

Two of the most merited specialists of tarand-graves in the second half of the 20th century have been Marta Schmiedehelm and Silvia Laul, who have both described tarand-graves as stone graves with low stone walls that were in turn usually buried under structural debris (е.g. Шмидехельм 1955; Laul 1962; 2001). No other interpretations have been considered, although in the 1990s Laul has referred in her works to the wooden mortuary houses known from the eastern Finno-Ugric peoples. She brings forth certain similarities between Inland Estonian tarand-graves and eastern Finno-Ugric mortuary houses - both structures are collective graves for cremation burials, comparable in size and quadrangular shape, the main difference being the building material. Laul has suggested that Estonian tarand-graves carry a genetic connection to the mortuary houses of the eastern Finno-Ugric peoples rather than to the few early tarand-graves found in coastal Sweden and in Finland (Laul 1990). In her later writings, she nonetheless points out that such mortuary log houses have not been found in Estonia (Laul 2001, $188,219)$.

Vello Lõugas has written a special article on the subject of reconstructing tarand-graves. He believed that at the time the tarand-graves were in use the outside walls had been visible, whereas the structural rim of debris surrounding 
them was the more recent result of crumbling wall layers. The tarands that could reach up to $75 \mathrm{~cm}$ in height were supposed to have been filled with stones on the inside (Lõugas 1975). In most cases, archaeologists have avoided the topic of the original shape of the tarand-graves; after excavations, usually only the lowest stone layer of the grave enclosures is left open and the remainder of the stones are removed. The Kõmsi and Lehmja-Loo single tarand-graves, however, were reconstructed by Lõugas in the form of $50 \mathrm{~cm}$ high rectangular enclosures laid of limestone slabs and filled with stones. Also a low stone heap was formed on the top of the grave (Fig. 2).

The 1995-1996 excavations at the Tõnija Tuulingumäe tarand-grave in Saaremaa showed that the partly limestone, partly granite tarand walls had crumbled both inwards and outwards, with the original height of the walls having reached up to $60 \mathrm{~cm}$. Consequently, the tarands could not have been completely filled with stones (Fig. 3), which is also supported by the fact that most of the tarand-graves - Tuulingumäe among them - have not contained enough stones for them to be filled with and to include even extra stone heaps on top. The reality is quite the opposite - tarand-walls are often detectable already before the object is excavated, i.e. the stones comprising the actual enclosure sporadically protrude above ground level. The likeness the tarands bear to house bases is also manifested in folklore, as locals tend to associate the remains of tarand-graves with church or

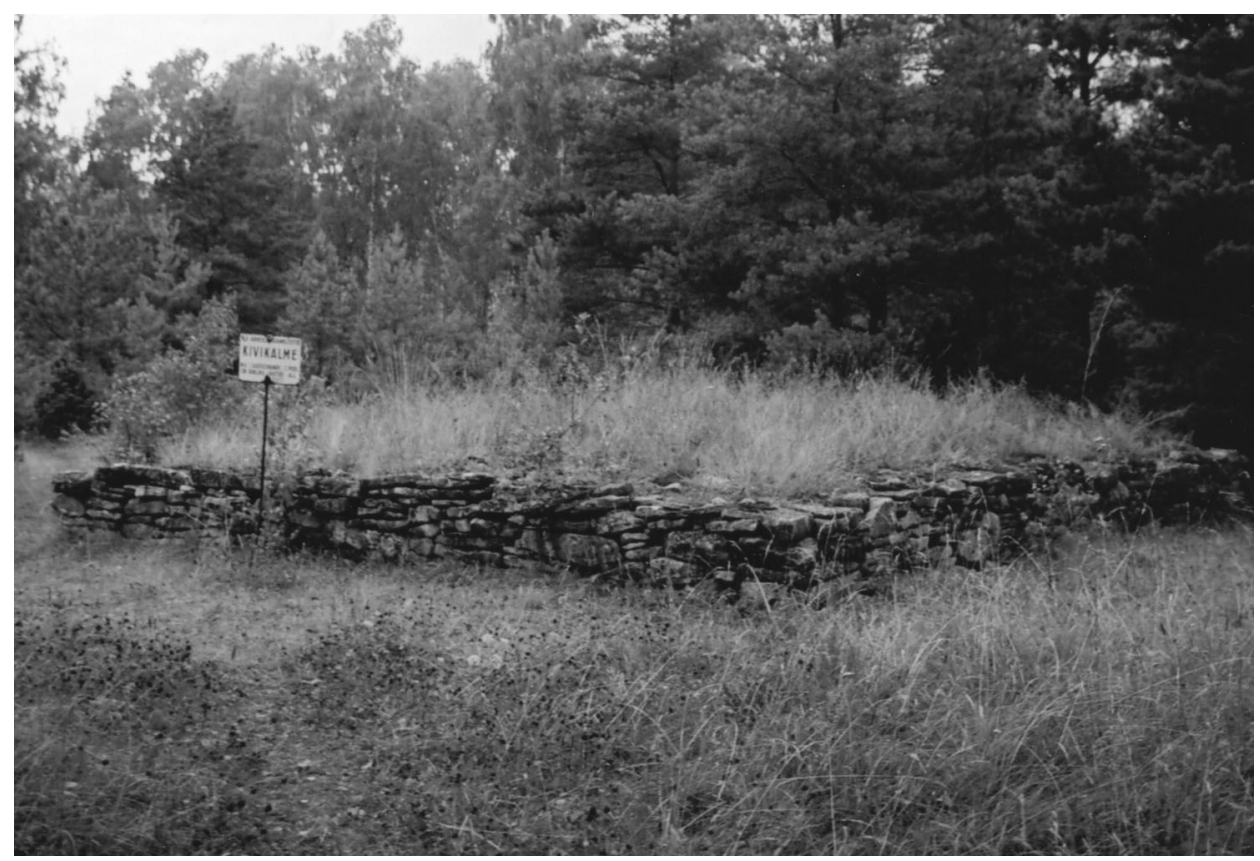

Fig. 2. Reconstruction of a single tarand-grave at Kõmsi, western Estonia. Photograph by the author. Joon 2. Ühetarandilise kalme rekonstruktsioon Kõmsis Lääne-Eestis. Autori foto. 


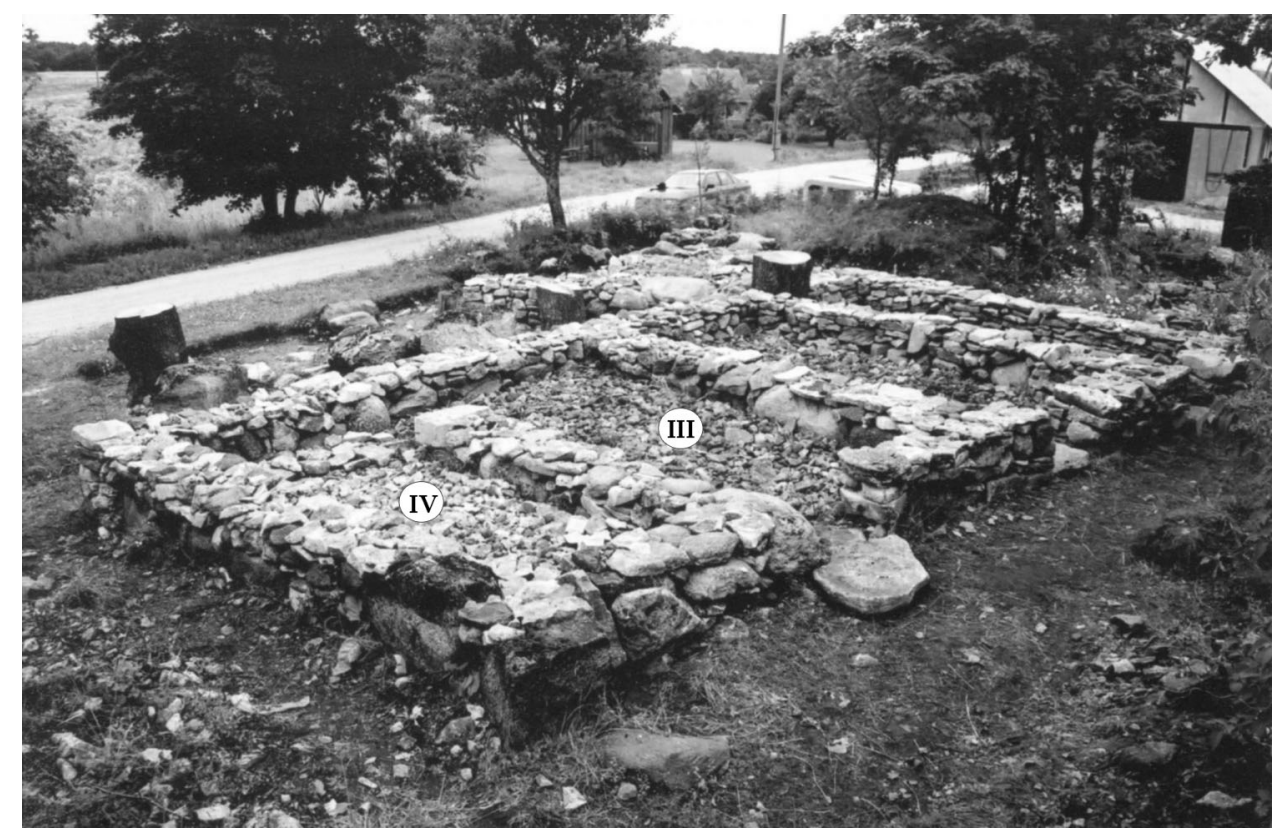

Fig. 3. Reconstruction of Tõnija Tuulingumäe Roman Iron Age tarand-grave, Saaremaa. Photograph by the author.

Joon 3. Tõnija Tuulingumäe rooma rauaaegse tarandkalme rekonstruktsioon, Saaremaa. Autori foto.

chapel ruins (see examples in Lõugas 1975) - in many cases, unexcavated tarandgraves do resemble old building foundations.

In Estonia, only one regular-shaped tarand-grave has been investigated after the Tõnija Tuulingumäe grave - the Uusküla II grave in North Estonia, excavated by Lang. The Uusküla II also had tarands laid of limestone slabs that had not been entirely filled in with stones. Proceeding from the notions of many earlier researchers, Lang has suggested that infill stones were usually added with every new burial, but neither Tuulingumäe nor Uusküla II graves had been buried "full" (Lang 2000, 147-161; see earlier discussions of the topic in Vassar 1943, 295-296; Lõugas 1975). The author of the present paper would maintain, however, that the phenomenon should be seen as a constructional characteristic that earlier researchers have failed to notice. Lang's theory is also contested by the fact that the remains of at least 27 burials (Lang 2000, 153-154) were found from the Uusküla grave, which, considering the size of the grave, is quite a large number. Therefore it could not be said that the grave contained less burials than is usual for tarand-graves. From the Tuulingumäe tarand-grave, the remains of about 30 people were recovered from two enclosures, while the two remaining tarands were almost devoid of any burials (Mägi 1999). Yet the stone infill was the same for all the tarands of the grave. 


\section{Tarand-graves as cult and/or burial places}

Most of the regular-shaped tarand-graves in Saaremaa and Coastal Estonia have been dated to the very end of the period such graves were in use, viz. the 4th-6th centuries. Comparative research of Couronian graves from the same era has given reason to believe that regular-shaped tarand-graves were erected, at least in Saaremaa, already in the (2nd?)-3rd centuries, thus about the same time as in Inland Estonia. This variance in dating was brought about by the earlier tendency to compare the material from Saaremaa's tarand-graves to that of mainly Virumaa County in Mainland Estonia, without paying attention to the distribution of similar artefact types in Roman Iron Age Couronia and north-eastern Poland, though in differently constructed graves (see also Mägi 2005; in print, a).

The Coastal Estonian tarand-graves with regular-shaped ground plans do differ to some extent from the Inland Estonian tarand-graves - they are not as big, usually comprising about 3-4 tarands. Aside from a few exceptions (e.g. Mäletjärve), single tarand-graves seem to be a predominantly Coastal Estonian phenomenon. Cremation has been the prevailing burial type in Inland Estonian tarand-graves, while across the coastal parts of the Estonian mainland secondary inhumation burials occur alongside cremations, and on Saaremaa Island the dominant funerary custom appears to have been the partial depositing of uncremated bones.

The excavations of four-tarand-graves at Tõnija Tuulingumäe demonstrated that the tarands had not been completely filled inside, the walls had reached up to half a metre in better preserved sections and been at least partially dry-laid of limestone slabs. There was a separate entrance to every tarand in the Tõnija grave that had at least in one case been clearly marked with flagstones (Fig. 4). The oldest part was comprised of two enclosures, one of which could be reached via the other (Fig. 5).

The Tõnija tarands contained a layer of the typical, head-sized infill stones which is where the majority of bones and artefacts were found. The infill stones were covered with limestone rubble, possibly from crumbled limestone slabs, which at places seems to have formed some sort of a pavement. Remnants of limestone slate pavement could also be found from under the infill stones. There were smaller stones almost everywhere beneath the infill - as the subsequent reconstruction of the cult platform proved, those stones had been essential for achieving a firm and steady stone surface without having to use slabs.

I would like to reflect here more closely on the subject of "empty" tarands. The excavations of the outermost tarand of the Jaagupi tarand-grave are claimed to have been the first time no bones or artefacts were uncovered from some enclosures of a tarand-grave (Laul 1962, 20). Proceeding from the notion of every generation building a new tarand section, tarands void of finds are generally associated with the possibility of the tarand having been erected, but for some reason never been buried into. Also the easternmost tarand of Tõnija Tuulingumäe was lacking any artefact finds or bone material. A similar picture emerged from the westernmost tarand (tarand IV) that contained only a few pieces of 


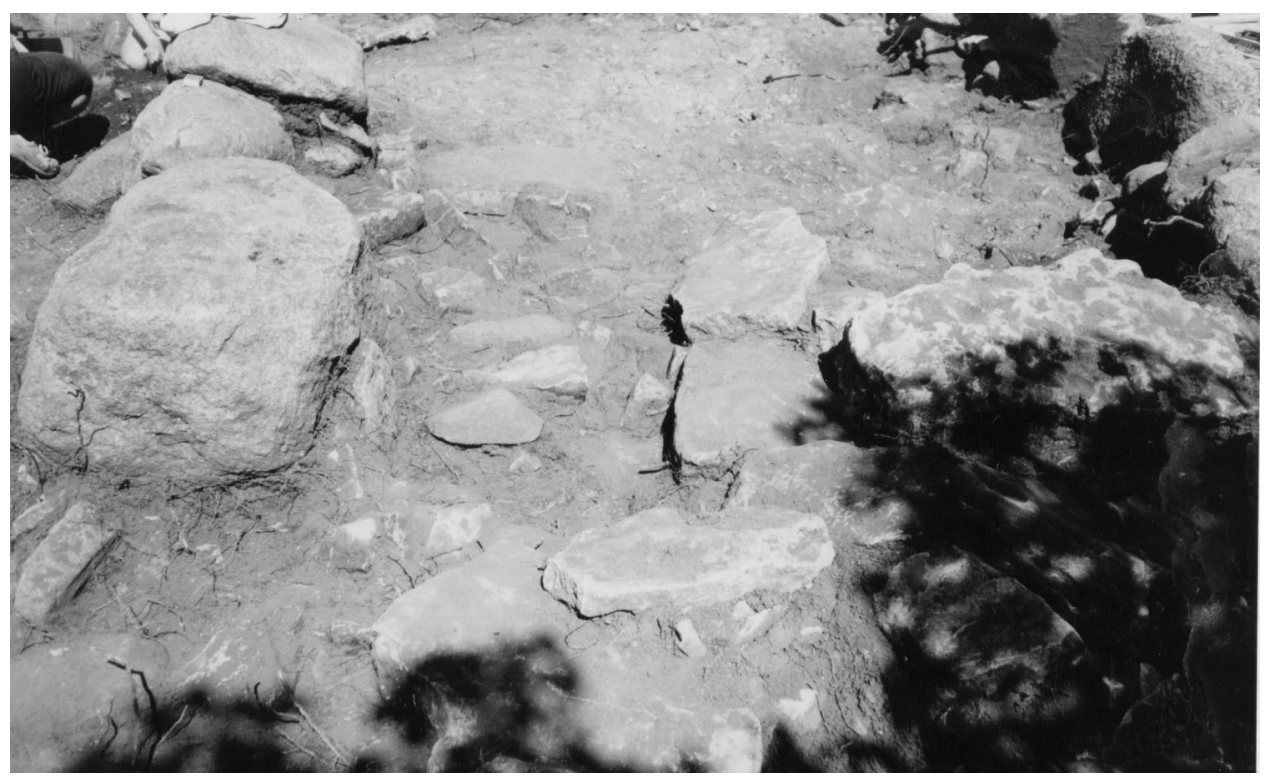

Fig. 4. Entrance to tarand III of Tõnija Tuulingumäe. Photograph by the author.

Joon 4. Sissepääs Tõnija Tuulingumäe III tarandisse. Autori foto.

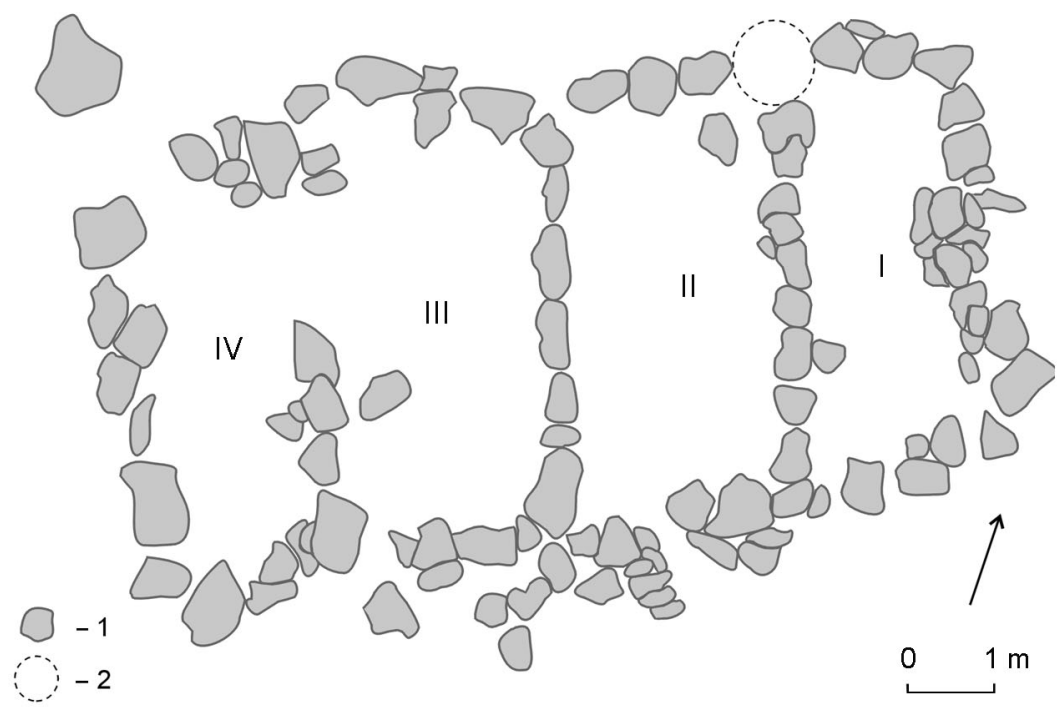

Fig. 5. Tõnija Tuulingumäe Roman Iron Age grave, possible foundation of a timber building. Plan of the site. 1 foundation stones, 2 post hole.

Joon 5. Tõnija Tuulingumäe rooma rauaaegne tarandkalme, võimalik palkhoone vundament. Kaevandi plaan. 1 vundamendikivid, 2 postiauk. 
pottery and some human bones, with animal bones making up the bulk of the find material. There were numerous burials in the adjacent tarand (tarand III). It should be kept in mind here that the entrance to tarand III was conspicuously marked, while tarand IV could only be accessed through tarand III - meaning that the only gap in the enclosing wall of the fourth tarand was situated between the two tarands. ${ }^{4}$ The overall impression is that the construction had been erected from the start as a two-room structure with one of the rooms designated for burials and the other mainly for sacrifices and other rituals. This "passable room" phenomenon seems to be indicating the existence of a one-time building rather than an open space enclosed by a stone wall.

From the constructional aspect it should be mentioned that there was no northern cornerstone between tarands I and II of the Tõnija grave; instead, there was a 1-m-diameter pit with stones laid on its bottom. Later excavations at the cult site near-by revealed more such pits. Those pits can be interpreted as the post-holes of large wooden pillars. ${ }^{5}$ Although the height of the pillars is not known, the presence of a post-hole instead of a cornerstone indicates that at the construction of more recent tarands the builders must have made use of the continually standing pillar.

Altogether, one can say that there are numerous indications implying a possible former status of the Roman Iron Age Tõnija tarand-graves as horizontal log houses built on stone foundations (see also Mägi-Lõugas 1997); at the same time there are no facts that would clearly contest this hypothesis. In the light of ethnographic data, the hypothesis is supported by the ground plan, size and entrance locations of the tarands. Still, it is very difficult to prove this hypothesis, as the timber constructions set in between and over the limestone parts do not preserve and there was no reason for digging post-holes in the stony ground. It is also rarely that post-holes occur at archaeological settlement sites (see, e.g., Lavi 1997, 120) and in ethnographic architecture, especially in Coastal Estonia.

It is worth noting that the Tõnija Tuulingumäe cult-house beside the stone grave with irregular enclosures had stood in its place already centuries before the tarand-grave was built. Five pits lined with limestone slabs were uncovered in the $4 \times 7 \mathrm{~m}$ stone platform of the cult house. The few fragments of human bone found there suggest that the pits had been used for processing the bones before they were buried into the irregularly shaped tarand-grave. The thin charcoal layer that was detected all over the platform indicates that a wooden, probably horizontal $\log$ construction must have stood on the stone foundations (Mägi 2001; Mägi \& Mägi 2002).

The author believes that the likelihood of a Roman Iron Age horizontal log construction having been situated at Tõnija is enhanced by the fact that at Lepna,

${ }^{4}$ In the course of the excavations, another gap was uncovered in the NW-corner of the tarand, but that had apparently been caused by the corner-stone having slid down the slope for about $1 \mathrm{~m}$.

5 The laying of stones on the bottom of pits dug for bigger constructions is caused by the local climate - otherwise, the ground that freezes in winter and then thaws would shift the construction from its original spot. The same technique is used for building stone walls in the countryside. 
only $1.2 \mathrm{~km}$ away from Tõnija, the remains of a partly underground mortuary house were discovered during the archaeological excavations in 2002-2003. Mortuary and/or cult houses must have therefore been characteristic of the Tõnija region both immediately before as well as after the Roman Iron Age. Under closer scrutiny, the material from other Coastal Estonian tarand-graves suggests that actually more mortuary log houses have been excavated.

\section{Migration Period mortuary house at Lepna}

The Katkuauk grave at Lepna, situated on the former coastline, $1.2 \mathrm{~km}$ away from the Tõnija gravesite, gave the impression of a hollowed-out depression in the middle of it even before the excavations started. In the course of the excavations it became apparent that the object was not a common stone grave, but it comprised the remains of what had been a partly wooden, partly stone construction (Mägi 2004; Fig. 6). In the centre of the structure there was a pit in the shape of a rectangle; the pit measured $80 \mathrm{~cm}$ in depth from the surrounding ground. It was girded by a low wall that consisted mainly of the soil that had been dug out of the pit. The surrounding stone structures were situated upon the wall, indicating that the construction process had started with the digging of the pit.

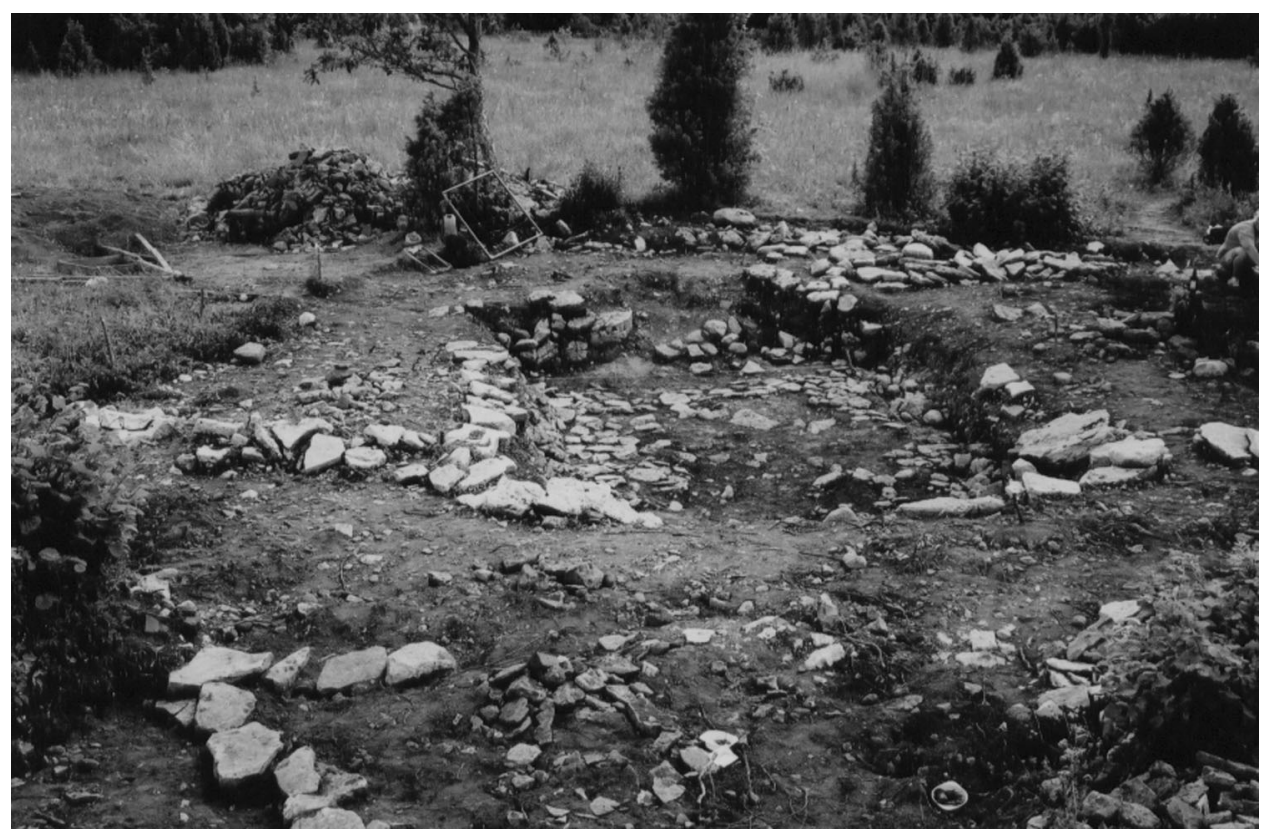

Fig. 6. Remains of the Lepna mortuary house after excavations. Photograph by the author.

Joon 6. Lepna surnumaja jäänused pärast kaevamisi. Autori foto. 
The pit was surrounded by a low, dry-laid limestone foundation in the size of $8.8 \times 5.3 \mathrm{~m}$. The pit itself had become filled with crumbled stones and soil. The rubble layer was thinner in the middle of the pit and thicker at the walls, where it mostly consisted of the stones that had fallen from the disintegrating limestone wall. A curious circumstance should be pointed out here: no foundation had been preserved in the southern half of the SW wall, on account of which that side also contained no crumbled debris (Fig. 7). There were no traces of a stone wall on that side, which suggests that the pit-house had either been partly open or, what is more likely, had a wooden wall without stone foundation at one end. Both of the shorter walls had openings in the wall base, which can probably be interpreted as entrances into the building.

The bottom of the pit was covered with a well-preserved flagstone pavement. In the SE corner, right beside the supposed entrance, traces of a hearth were
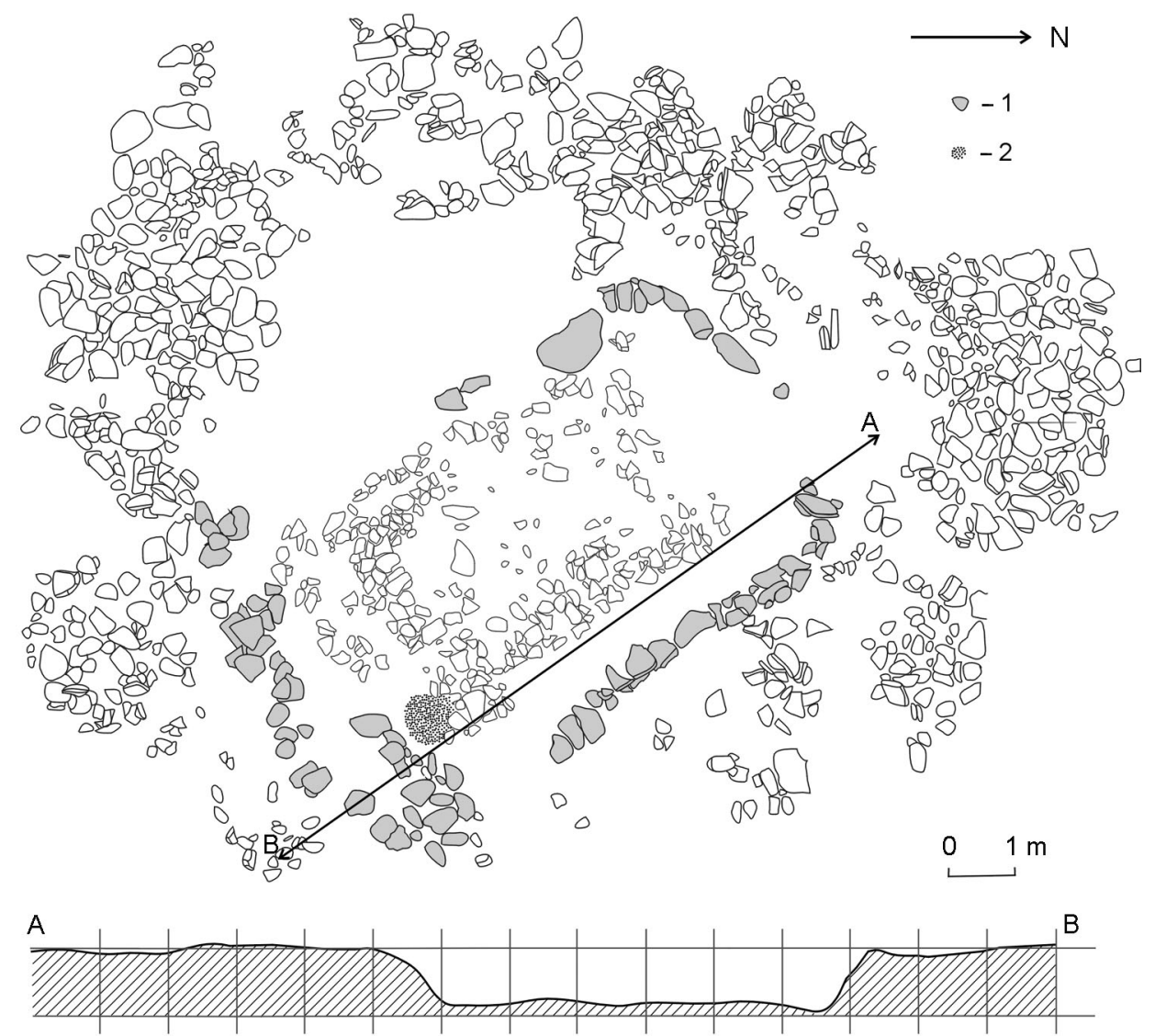

Fig. 7. Lepna mortuary house. Plan of the site. 1 foundation stones, 2 fireplace. Joon 7. Lepna surnumaja. Kaevandi plaan. 1 müürialuse kivid, 2 tulease. 
found - there was a charcoal stain of $60-70 \mathrm{~cm}$ in diameter and some burned stones. The fireplace does not appear to have been used very often, which, considering the function of the building, is not unexpected.

This type of a ground house had to be covered with a roof. Ethnographic parallels indicate that in dry-laid limestone buildings the roof rested on a timber frame erected on the ground. As this kind of a wooden construction lacked postholes, probably no trace would be left of the timber parts after 1500 years. The only reference to the one-time timber frame can be seen in the circularly placed limestone slabs that were uncovered from the NW corner of the wall base - these slabs had probably surrounded the corner post.

The northern, NW and NE sides of the pit were bordered with a smaller debris belt ( $1.5 \mathrm{~m}$ wide) that also yielded some bones and artefact finds. In the northern and western parts of the excavation, outside the limestone rubble, there was an area that contained mainly limestone slabs that had either been thrown or fallen there from among stones gathered for some construction. It is likely that this area had been formed in the course of some dismantling activity. Even though such a tendency has never been monitored at any other Estonian prehistoric antiquities, there remains a possibility that the mortuary building had been demolished some time after falling out of use. This could have been brought about by the emergence of a new elite family, who disdained the conspicuous grave structures as a manifestation of the former chiefs' power. The abandoning and gradual decay of the mortuary building could also have been caused by the onset of a new ideology.

In case the construction was wilfully dismantled, it would have been more practical to have the slabs used for building new graves or other structures, as the limestone slabs seem to have been hand-picked. The possibility that the roof of the building was covered with limestone slabs should also be considered here (Fig. 8); when the construction was abandoned and started to fall apart, some of the roof tiles would have fallen under the eaves, while others would have dropped inside the building after the truss under the tiles had decomposed. Broken flagstones were indeed found throughout the upper layers of the pit and also in the surrounding area. If one assumes that the limestone pieces and rubble covering the pit and an area about $1.5 \mathrm{~m}$ wide around it originate from a limestone-tiled roof, then it follows that the underground chamber had made up only one section of a larger building. This assumption is supported by the fact that while bones and artefacts were found in the limestone rubble, none were revealed among the limestone slabs, or around them.

The probable roof tile belt remains about $1.5 \mathrm{~m}$ away from the northern and western sides of the pit, while on the southern side it merges with the stone foundations surrounding the pit. On the eastern side there does occur an area of limestone rubble containing burials, but it contains no pieces of limestone slabs. That side of the grave is abruptly juxtaposed with a field; it is possible that some of the stones may have been removed from there during the Soviet-time melioration activities.

The tiled roof must have therefore been slanting in four or at least three directions, which would indicate the use of hipped roof, which has been considered 


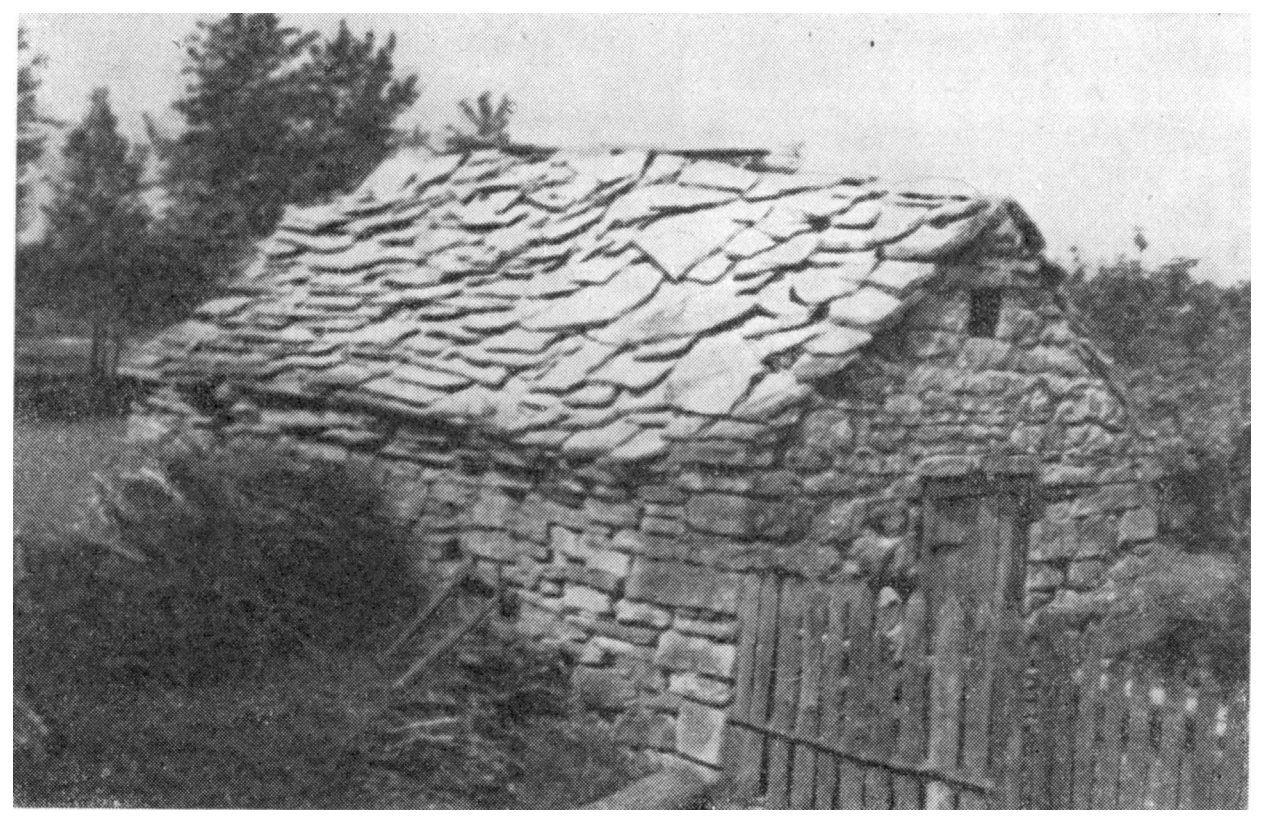

Fig. 8. Archaic summer kitchen in Saaremaa (Ränk 1939).

Joon 8. Arhailine suveköök Saaremaal (Ränk 1939).

a very likely roof type for prehistoric buildings by archaeologist Evald Tõnisson (Тыниссон 1980). To prevent the roof tiles from sliding, the roof of the Lepna house could not have had a very steep slant (on the construction of stone roofs see, e.g., Ränk 1939, 84-86). A timber frame probably surrounded both the underground part of the house and the area around it. The fact that the foundation stones have crumbled along the slopes of the pit may indicate that the walls of the central construction had been entirely laid of stones; on the other hand, the absence of debris and stone foundations at the SW wall does indicate the possibility of a timber wall. The pit-house could be entered through the two facing entrances in the shorter walls. As the southern side of the pit has merged with the layer of crumbled roof tiles and the entrance on that side was marked more clearly, it is probable that the main entrance to the building had stood there.

The building itself may not have been very high. It seems that the pit-house had been the most important part of the building, as most of the finds and bones were uncovered there. Drawing on ethnographic parallels, it can be suggested that the area surrounding the pit had been merely a repository space under the eaves that could have been quite low, especially on the edges. The walls may have only enclosed the pit-house that was bordered from three sides by an open gable. Considering the fact that the main part of the building was built about $80 \mathrm{~cm}$ into the ground, that chamber could have stood only $1.2-1.5 \mathrm{~m}$ above ground even if it had a ceiling (Fig. 9). 


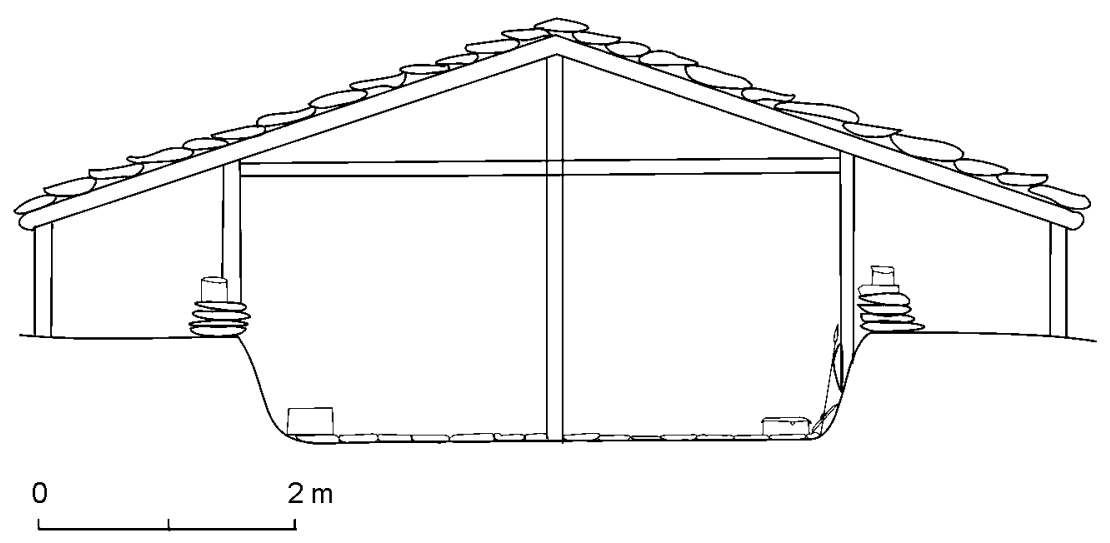

Fig. 9. Possible reconstruction of the Lepna mortuary house.

Joon 9. Lepna surnumaja võimalik rekonstruktsioon.

\section{Other possible mortuary houses in Estonia}

Many other Saaremaa graves, such as Liiva-Putla, Mäla, and Võhma, resemble the Roman Iron Age regular-shaped tarand-grave of Tõnija Tuulingumäe both in their construction and find material. All of these are multi-period stone grave complexes characteristic of Saaremaa, in which later constructions are built partly over the earlier ones. Some of these complexes lack sufficiently detailed excavation reports to say anything conclusive, but it is quite probable that these Roman Iron Age constructions could have been mortuary houses resembling the Tõnija example.

There are several probable mortuary houses among the North Estonian antiquities. Above all, the Uusküla II and Tõugu IIB single tarand-graves should be considered here - these were excavated in the 1990s with modern methodology and have been dated to the late Pre-Roman Iron Age. The excavating archaeologist Lang has interpreted both graves as boxes with dry-laid walls, partially filled with stones. The Uusküla II grave has also been reconstructed that way on the site (Lang 2000, 100-107, 147-161). Proceeding from the argumentation presented in the current article and the data from earlier excavation reports, a large part of North Estonian - but apparently also Inland Estonian - Roman Iron Age tarand-graves could be reconstructed as horizontal log constructions (Шмидехельм 1955; see also Laul 2001).

The Paju grave in Western Saaremaa that was excavated in 1975 represents an intermediate form between the Roman Iron Age tarand-graves, or mortuary buildings, and the mortuary houses from the Migration Period. At Paju, timber remains were found encircling a rectangular cairn. The latter bore resemblance to the infill stones of tarand-graves, and most of the finds and bones were found from there. Under the stone layer and the intermediate stratum beneath it, a layer of charred wood and fist-sized granite stones were found. The archaeologists who excavated the grave hesitatingly suggested that the aboveground part of the grave 
might have been built of wood (Tamla \& Jaanits 1977). The local sandy soil type had enabled the preserving of timber remains, which is a very rare occurrence in Saaremaa. The site gives the impression of a tarand-like grave that has contained a horizontal log construction instead of the usual stone walls. Correlations with the Lepna site suggest that there must have been a corner-joined, horizontal log house here besides the tarand-grave. In contrast to Lepna, however, the house had been built on the ground, not on a dry-laid foundation, and it was not a pit-house.

Judging by the material presented in past excavation reports, the possibility of Lepna-type mortuary houses should be considered in the case of some Roman Iron Age and Migration Period single tarand-graves situated in North Estonia, especially in the Tallinn area (like Proosa, Lagedi XIV C and XV B, Lehmja-Loo I; see Spreckelsen 1927; Lang 1996, 322-323, 240), but also a few 4th-5th (up to 7th ?) century multi-tarand-graves (like Saha D, Viimsi I and II; Spreckelsen 1907, 384 ff; Lang 1987; 1993; 1996, 241-246) in the same region. Rectangular limestonetiled floors resembling the Lepna example (though missing the encircling wall) have been uncovered from the Lagedi XIV C and XV B graves. According to the excavating archaeologist Arthur Spreckelsen, the original measures of the XIV C grave were $4 \times 4 \mathrm{~m}$, of which $2 \mathrm{~m}^{2}$ were covered by a granite patch and $11 \mathrm{~m}^{2}$ were paved with limestone slabs. The construction lacked the side walls and infill stones that are typical of tarand-graves (Spreckelsen 1927, 44-47; Fig. 10). Grave XV
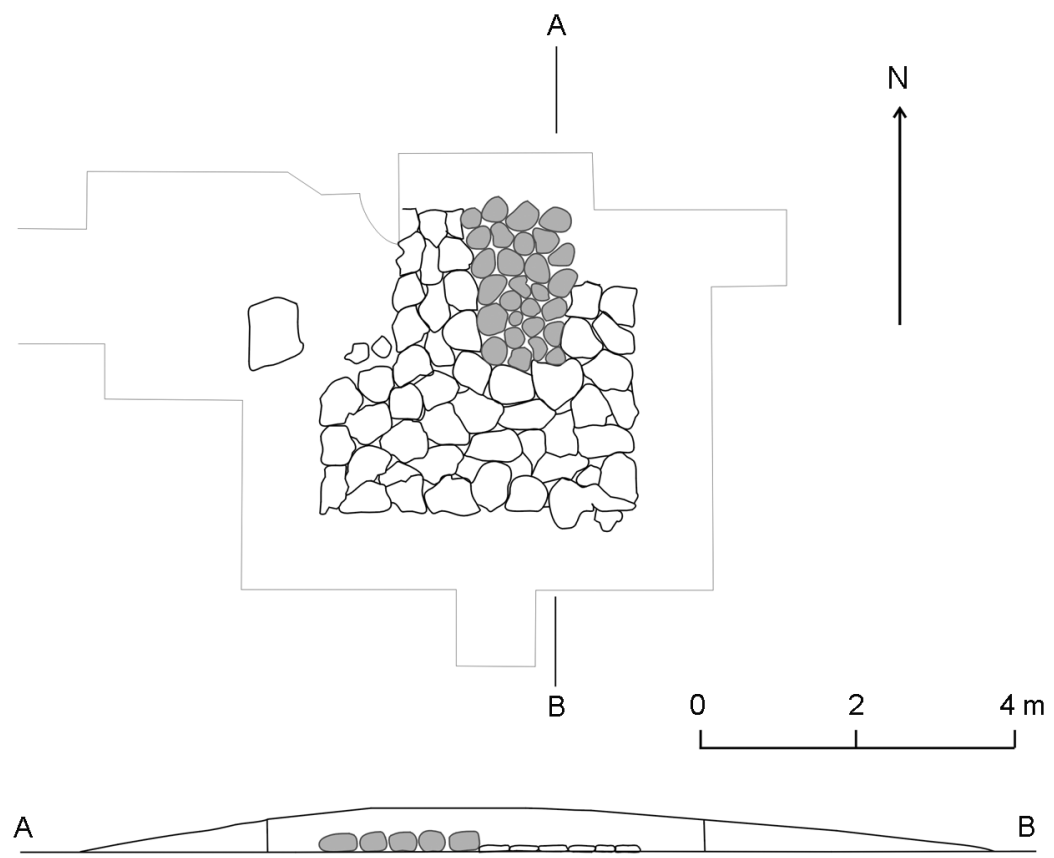

Fig. 10. Lagedi grave XIV C (Spreckelsen 1927, Plan 7).

Joon 10. Lagedi XIV C kalme (Spreckelsen 1927, plaan 7). 
comprised two rectangular areas paved with flagstone; of these, only grave B was excavated. There, too, a flagstone floor was revealed $(6 \times 4.75 \mathrm{~m})$, as well as some poorly preserved portions of stone wall on the western and probably also on the southern sides of the grave. An earlier, limestone-tiled quadrangular pit was discovered beside and partly also beneath the western wall. The charred and decayed timber remains that were found in the flagstone pavement together with bone and artefact remains point to the possibility of a horizontal log construction (Spreckelsen 1927, 51-53; Fig. 11).

A multi-tarand-grave in the Tallinn area that deserves special attention is the Saha D grave, which was excavated in the period between 1904 and 1905 (Fig. 12). The grave consisted of two approximately same-sized tarands that measured about $8 \times 5 \mathrm{~m}$. For the most part, the limestone walls were only partly detectable; on the southern side of the grave the walls were entirely absent. Spreckelsen presumed
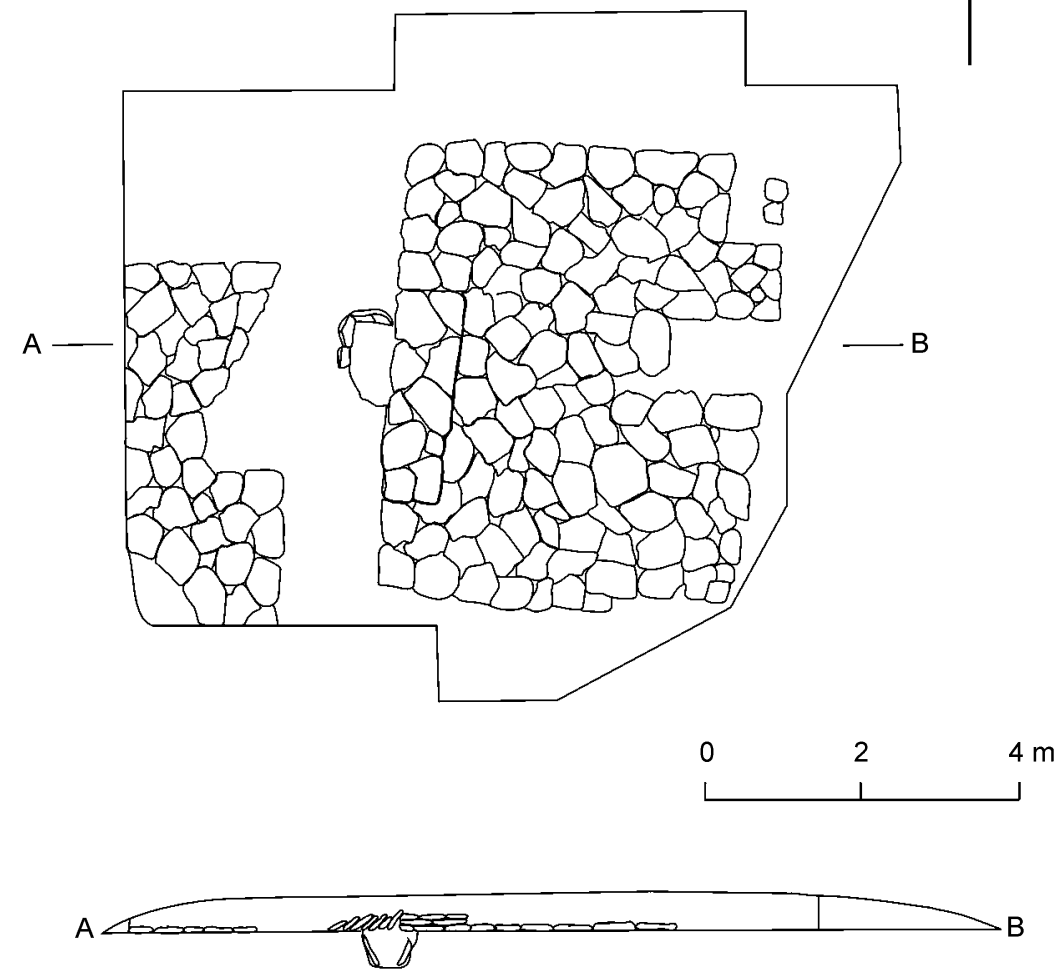

Fig. 11. Lagedi grave XV B (Spreckelsen 1927, Plan 8).

Joon 11. Lagedi XV B kalme (Spreckelsen 1927, plaan 8). 


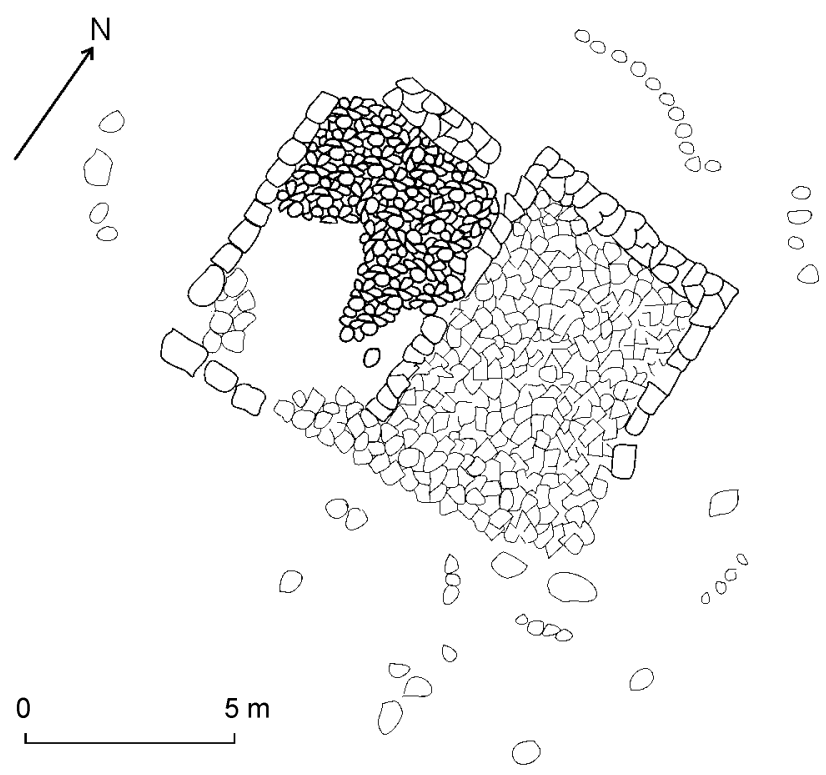

Fig. 12. Saha grave D (Spreckelsen 1907).

Joon 12. Saha D kalme (Spreckelsen 1907).

that some portion of the walls had been destroyed or remained unnoticed during the excavation; on the other hand, in the light of the data acquired from later excavations of tarand-graves with partial walls, this presumption does not appear logical - it is more likely that the grave had not been fully girded with stone walls from the start.

The eastern-side enclosure had been tiled with flagstone slabs, with the southern edge kept straight. An infill of head-sized stones only occurred in the northern part of the western enclosure. The paper discussing the grave creates the impression that the area between the walls had been covered with horizontally, diagonally or even vertically placed vast limestone slabs, but also a mix of limestone rubble and granite pieces, and soil. The text also mentions a gap in the dividing wall between the two tarands, but its function remains obscure; it is quite likely that the granite infill had simply reached the wall level.

Uncremated bones and artefacts were gathered from among the stones over the whole grave area. According to Spreckelsen, artefacts were mostly found in the top layer of the grave infill, right under the turf. Many finds and bones were recovered from the stone and rubble mix surrounding the tarands; a few discontinuous stone rows could be discerned from the debris (Spreckelsen 1907, 385-390). The grave was very rich in finds and could be dated to the 4th-5th centuries AD (Lang 1996, 246). 


\section{Parallels with ethnographic buildings}

The constructional details discussed above, as well as the ground plan of tarandgraves in general, resonate with an abundance of parallels from ethnographic sources and the house remains excavated at Late Iron Age, Medieval and Modern Age settlement sites. Even though the data comes from much later time periods, the archaeological remains of those buildings (or presumable remains, as is the case with ethnographic buildings) can be compared with the evidence that we have from tarand-graves.

Unfortunately, little is known of the architecture of the secular buildings from the period of the tarand-graves. On the late Bronze Age Iru hill-fort settlement, for instance, remains have been detected of up to 10-m-long and 3-5-m-wide houses, which probably had roofs that were supported by lines of posts in the middle of the construction. Those were buildings already erected in the horizontal log technique (Lang 1996, 38-40).

A large part of Coastal Estonia is standing on layers of limestone or till in which there is no need to dig holes for constructional posts. Horizontal log constructions seldom demanded posts, and in such cases limestones could be laid under the posts or some stones deposited around the posts. Both these variants could be very difficult to recognize in archaeological constructions that are rich in stones anyway. In Estonia, post holes that have been dug into the ground have been predominantly found in archaeological excavations of thicker, especially sandy soils, as for instance on hill-forts, and even then not very often.

An important point to be considered here is that mortuary houses cannot be directly compared with living houses. Even if the general structure does, at first sight, resemble that of a dwelling, it must be taken into account that mortuary houses had no need for heating nor, consequently, any heating device; the building material was probably chosen for its outward appeal, rather than for the keeping of warmth or other functional aspects. Stone might have been considered an everlasting material, consequently also more symbolic and also a more deferential material, which could explain the use of stone in mortuary houses while secular buildings were built predominantly of wood. It is quite possible that the architecture of sacral constructions was altogether more strictly reglemented than that of secular buildings: for example, new chambers or house parts tended to be added to sacral buildings in the East-West direction.

In the ethnographic material, the architecture of 19th and 20th century auxiliary farm buildings - rather than the farm-house itself - provides fitting parallels for archaeological mortuary buildings. The closest ethnographic complement is in fact the storehouse that often consisted of several adjoined chambers (Fig. 13). In summertime, but also during warmer winters, such storehouses served as sleeping quarters for the young (e.g. Ränk 1939, 313-324). The entrances to the chambers were usually located on one side of the building; sometimes, the intermediary rooms had no frontage or, on the contrary, no direct entrance and were to be accessed through adjacent chambers. In the cases when log houses had stone 

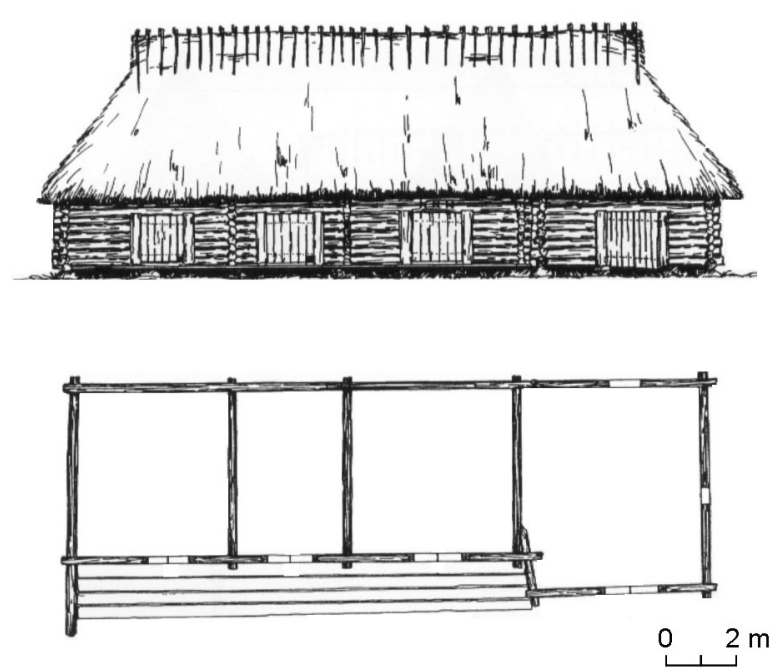

Fig. 13. Ethnographic storehouse from West-Estonia (Vernacular architecture, fig. p. 13).

Joon 13. Etnograafiline ait Lääne-Eestist (Vernacular architecture, joon lk 13).

foundations, the foundation walls may have been discontinuous, i.e. present under some and absent under other walls. As Coastal Estonia is rich in limestone, some walls were built entirely of dry-laid limestone, while others may have lacked even the stone foundation layer under the sill logs.

Similar fragmental stone foundations have been discovered at archaeological settlements (Lavi 1997; see also his article in the present issue). Dry-laid limestone foundations or simply stones pushed under the log walls are characteristic mainly of the limestone-laden Coastal Estonia (Fig. 14). Parallels can be drawn here with tarand-grave constructions that have also been frequently noted to lack some tarand walls. This phenomenon has usually been explained with dismantling activities (e.g. Laul 1962,16) or simply as "non-preservation" without further elucidation (e.g. Saha D grave, Jäbara B grave, Ojaveski grave; Spreckelsen 1907, 385-386; Шмидехельм 1955, Pl. VII, Fig. 35). In some graves, irregular limestone stretches rather than clear-cut limestone foundations have been found, which has also been explained by poor preserving conditions (e.g. Pada tarand-grave, Шмидехельм 1955, Pl. X). Those stretches actually resemble the irregular stone arrangements laid or rammed beneath corner-joined horizontal log walls.

The Lepna mortuary house, however, can be compared with the ground plan of Coastal Estonian ethnographic dwellings, especially if we proceed from the assumption that the pit-house was merely the central chamber of a larger building. The defining feature of the so-called West-Estonian-type barn-dwelling is the existence of additional rooms under the eaves surrounding the main room (Ränk 1939, $108 \mathrm{ff}$; Tihase 1974, $133 \mathrm{ff}$ ). In such cases, the central chamber has two 


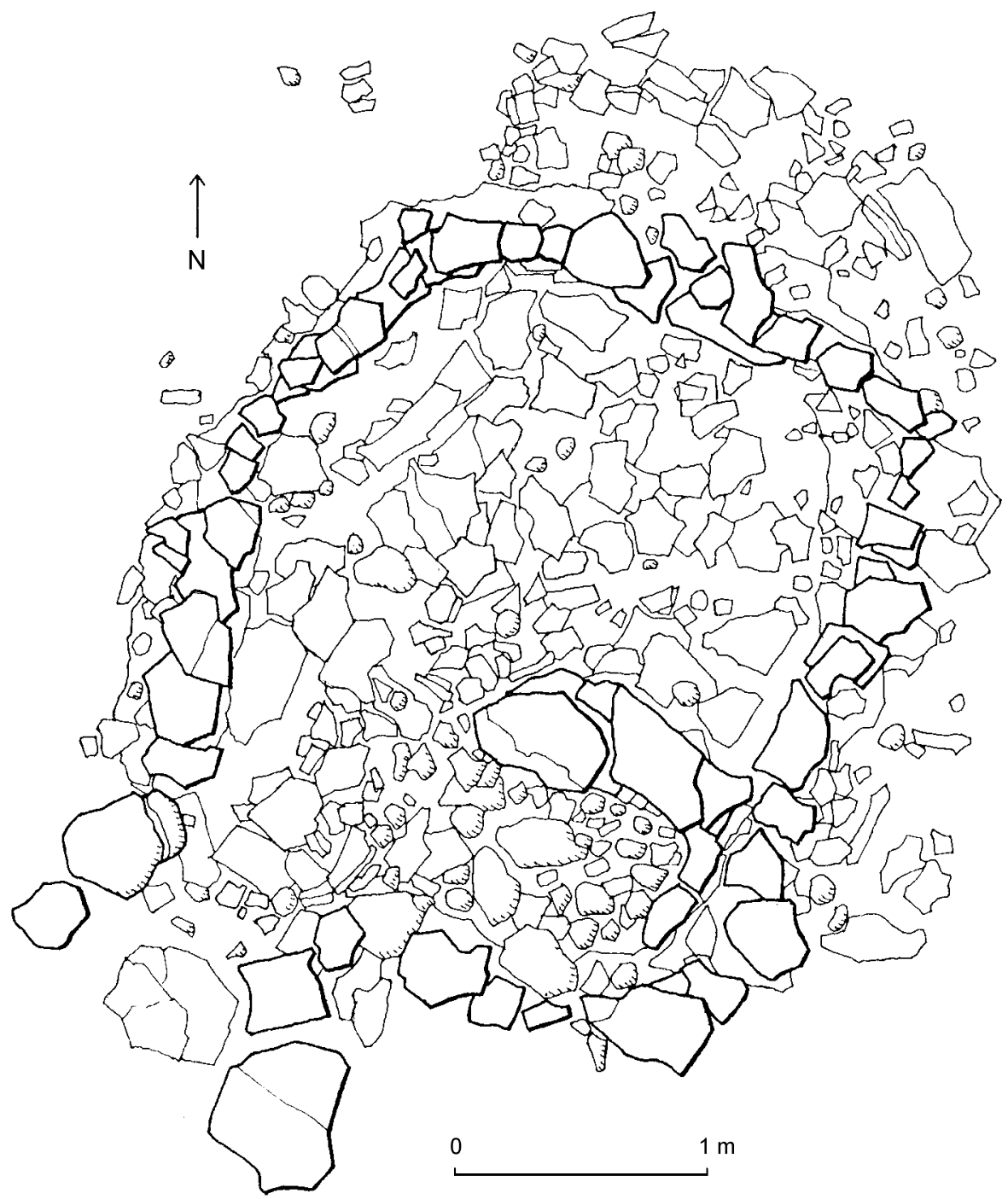

Fig. 14. Plan of an 18th century sauna-hut at Proosa, North-Estonia, with surrounding debris (Lavi 1997, Fig. 12).

Joon 14. 18. sajandi sauna plaan Proosalt Põhja-Eestis koos äärevaret meenutava kivise vööndiga hoonest väljaspool (Lavi 1997, joon 12).

entrances in the shorter walls (compare Fig. 15), as could also be deduced at Lepna. The tarand walls of Inland Estonian tarand-graves indicate that some of the tarands have been situated inside larger tarands (compare with, e.g., Sadrametsa grave, Virunuka grave; Laul 2001, Figs. 7, 23). Archaeological excavations at settlement sites reveal a very similar sight: the central room and its stone foundations are often encircled by an additional stone foundation. The foundation 

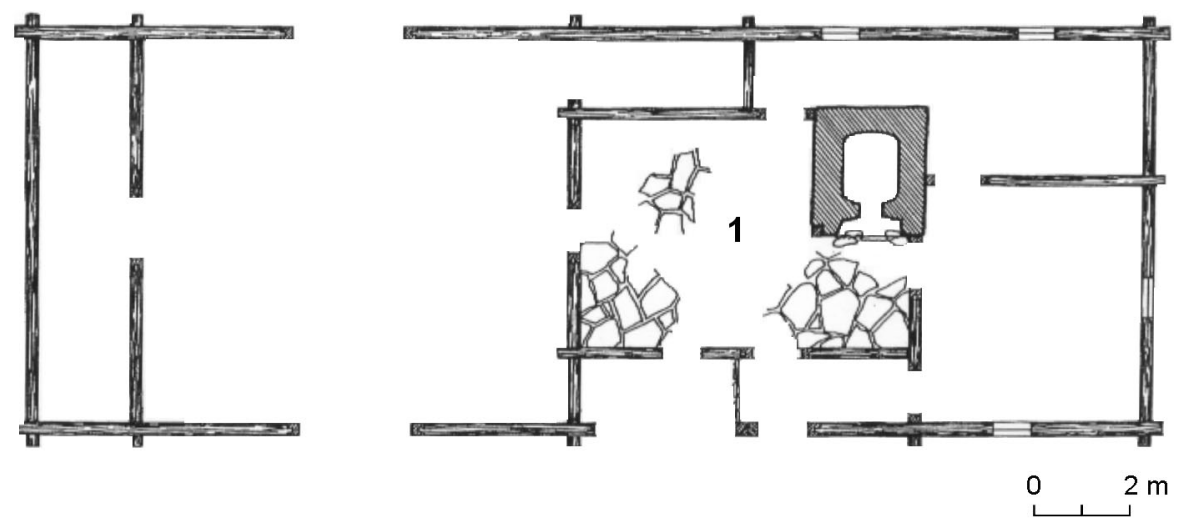

Fig. 15. Plan of ethnographic barn-dwelling from western Estonia (Vernacular architecture, fig. p. 17). 1 central room.

Joon 15. Lääne-Eesti etnograafilise rehielamu plaan (Vernacular architecture, joon lk 17). 1 keskne ruum.

walls are discontinuous, and in many cases the actual scope of the building can only be established by the concentration area of finds, the scattered stove rocks or other similar indicators (see Lavi 1997; Fig. 16).

In its constructional details, the Lepna pit-house (or -chamber) resembles the pit-houses known from archaeological and ethnographic materials. Archaeologically, such constructions have usually been interpreted as summer kitchens (Lavi 1997; see also his article in the present issue), but ethnographic record shows that in Coastal Estonia temporary fishing huts have often been built into the ground in a similar manner (Tihase 1974, 167-171).

The chambers that were annexed to the central living room were commonly used as store-rooms, occasionally also as summer-time living quarters. These chambers were 1.5 to $3 \mathrm{~m}$ wide, hallway-like unheated rooms that were sometimes divided into several sections (Lavi 1997, 117). In Estonia, there is no data of ethnographic dwelling houses with subsurface living quarters. Traces of narrow, elongated, sometimes only 1-metre-wide unheatable store-rooms have been identified beside archaeological house remains (see Uderna III smoke cottage site; Ланг \& Лиги 1990, Pl. XXI, 1). Narrow elongated tarands are fairly widespread in tarand-graves (e.g. Toila grave, Uusküla II grave, Virunuka grave; Шмидехельм 1955, Pl. III; Lang 2000, Fig. 60; Laul 2001, Fig. 23).

Surrounding structural debris on the tarand-grave sites is an issue that requires special attention. In stone graves of Saaremaa, the debris is mostly made up of small limestone slabs, while in the Inland Estonian tarand-graves it often consists of several layers of granite rocks. Various theories concerning the origin and/or function of the debris surrounding the graves have been suggested by Estonian archaeologists: they have been interpreted as special parts of the grave (e.g. Laul 2001, 194) or as residue resulting from the over-heaping (Vassar 1943, 295-296) 


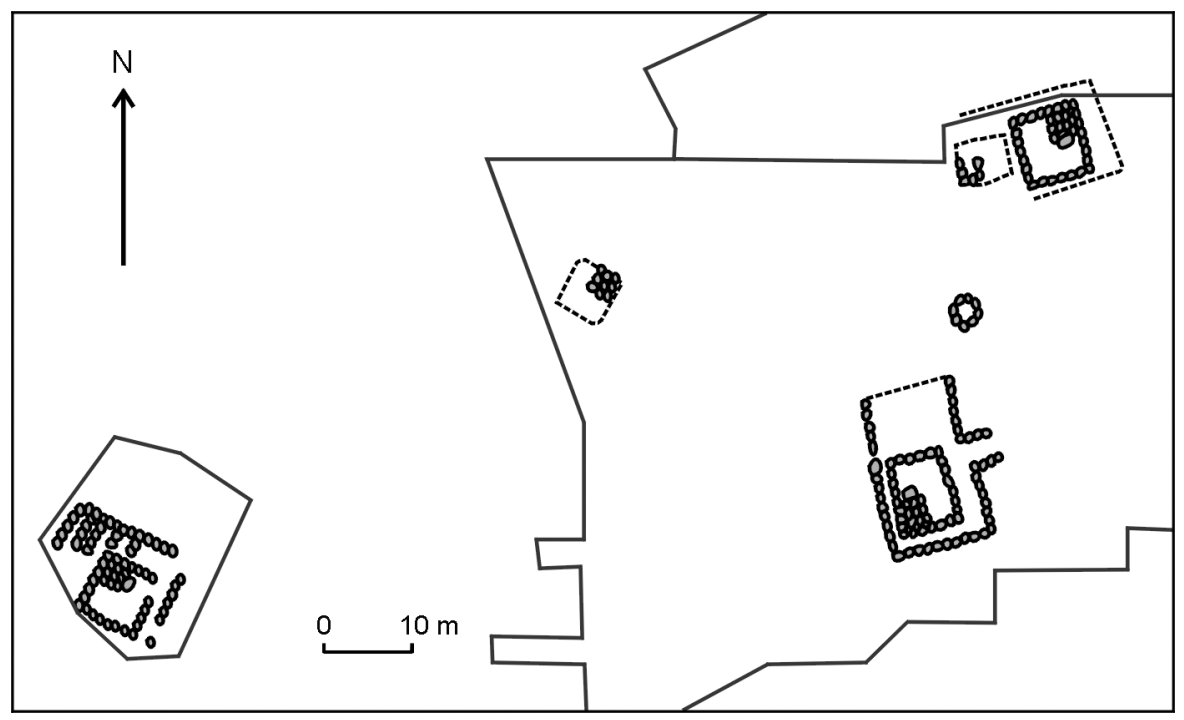

Fig. 16. Plan of archaeological building remains at Lehmja, North-Estonia (Lavi 1997, Fig. 3, detail). Joon 16. Lehmja arheoloogiliste hoonealuste plaan, Põhja-Eesti (Lavi 1997, joon 3, detail).

or crumbling of tarands (Lõugas 1975). At Tuulingumäe, the surrounding debris consisted of specially chosen limestone rubble and probably belonged together with the tarands; the limestone slabs that had slid off the tarand walls were clearly bigger and positioned on top of the debris. What is more, limestone debris could also be found in places where no other findings indicated the existence of limestone on the foundation walls. It may be that the surrounding debris served some function in the past - e.g. prevented the ground from becoming muddy or was there for some aesthetic purpose. The surrounding debris area itself must have been sacred, as is indicated by the bone and artefact finds acquired from such areas.

Similar stretches of limestone rubble surrounding house bases have been discovered at Varbola (Тыниссон 1980, Fig. 4), but also at some Viking Age harbour sites in Saaremaa (Mägi, in print, b). These are clearly cases of functional construction details. Also some sauna stove cobble patches (ca $1 \mathrm{~m}$ in width) stretching out of the sill-stone base areas have been discovered at archaeological settlement sites (e.g. Olustvere settlement). Used stove cobbles have probably been recycled for paving the house grounds (Lavi 1997, 90; see also his article in the present issue). The parallel with the limestone rubble is obvious; in locations where natural limestone was hard to come by, worn-out or rejected stove cobbles could be used for the same purpose.

Surrounding a building with limestone rubble could have been brought about by the need to prevent the grounds from becoming miry from eavesdrip. It has been noted that at Inland Estonian tarand-graves, structural debris usually occurs on the northern and southern sides - a phenomenon that has been associated with the planning of new tarands to the eastern and western sides of the grave 
(Laul 2001, 194). Conversely, there are also tarand-graves that are fully enclosed by a debris belt (e.g. Virunuka grave I; Laul 2001, 69-70). At the Tõnija tarandgrave, only the northern and southern sides were lined with structural debris. It should be emphasized, though, that in the case of the gable roof that is characteristic of Estonian ethnographic buildings, rain and thawing snow mainly run down in two directions (on the subject of roofs see Тыниссон 1980).

Probable fire-places have been found not only at Lepna but also at other Estonian tarand-grave sites (e.g. Jaagupi tarand-grave; Laul 1962, 20). Based on the data obtained from Scandinavian settlement excavations, it has been pointed out that if the fire-place has not been situated on the ground, but on raised benches, no notable evidence survives (e.g. Kristiansen 2002). Then again, it would be quite logical to assume that most mortuary houses did not have fire-places - there was no need to heat the house or to cook food etc., and the few fire-places found from grave sites are rather implying some ritual activities that required the use of fire.

The most significant constructional difference between both archaeological and ethnographic house bases and tarand-graves is the occurrence of infill stones inside tarand-graves (Fig. 17). Dwelling houses commonly had earth floors, sometimes also limestone-tiled or clay- and lime-plaster floors, but board floors definitely occurred by the end of the Iron Age at the latest (Ränk 1939, 68-72; Тыниссон 1980, 70; Lavi 1997, 104-106). In later times, an empty space was often left under the board floors of granaries and other store rooms to keep them

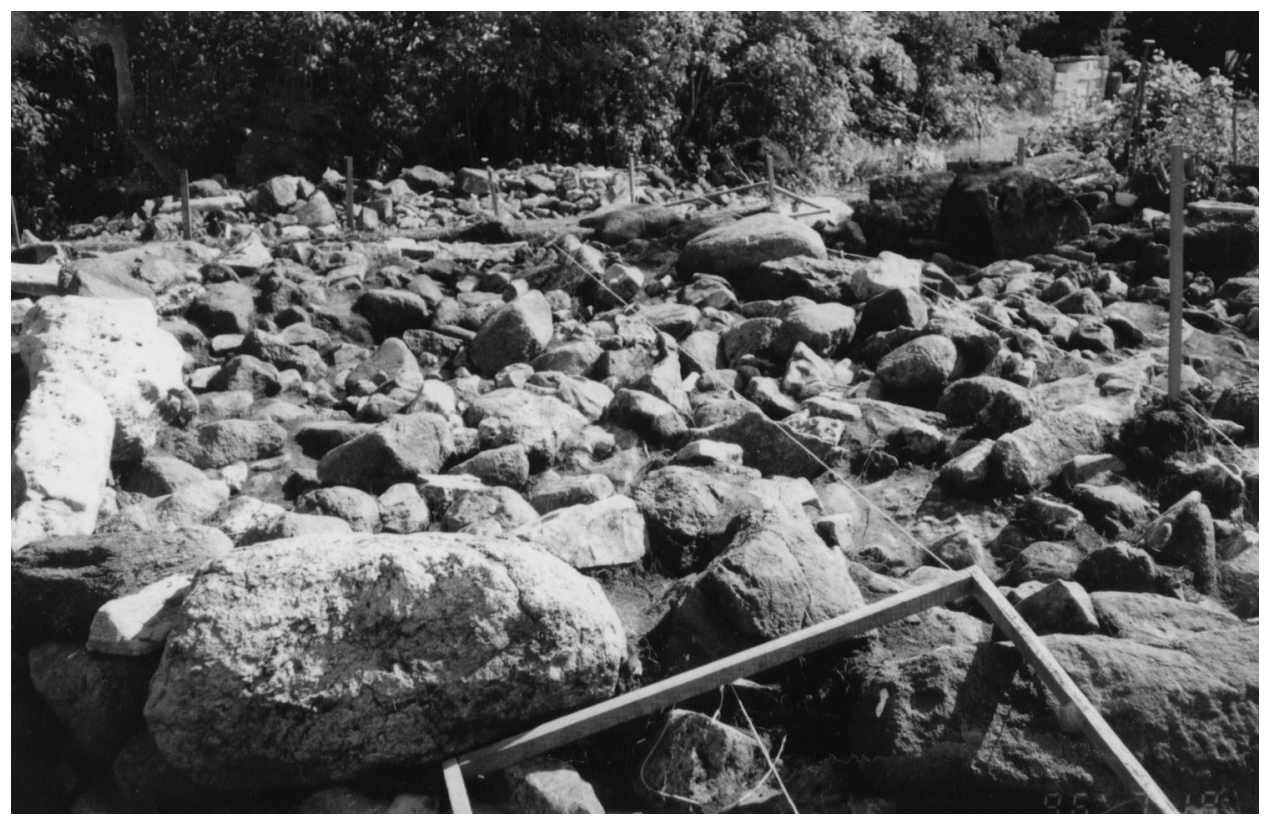

Fig. 17. The IIIrd tarand at Tõnija Tuulingumäe, infill stones. Photograph by the author. Joon 17. Tõnija Tuulingumäe III tarand, sisetäidise kivid. Autori foto. 
dry; sometimes, these spaces were used as repositories that could be accessed by removing floor boards (Ränk 1939, 316-317).

At the Roman Iron Age tarand-grave excavations at Tõnija, a layer of small limestone slabs was detected above the infill stones that could indicate the onetime limestone pavement in the grave. The sporadic distribution of find clusters in the grave gives reason to believe that when a new burial - collections of uncremated bones and artefacts - was brought into the grave, some infill stones were removed, the burial was placed in the created cavity and subsequently covered with stones. It is important to keep in mind here that no whole bodies have ever been recovered from regular-shaped tarand-graves of the Roman Age. In Inland Estonia, the tarand-grave burials are predominantly cremations, while in Coastal Estonia there also occurs the custom of uncremated secondary burials that involves the burying of only certain, previously crushed bones. As a result, little space was needed for placing new burials into the mortuary houses. At the same time, animal bones and pottery shards have been found from almost all the tarandgraves, as well as around the tarand-graves, which could be associated with the rituals - possibly sacrificial rites - carried out at the grave sites. Thus it can be said that the tarand-grave was in use also in between the funerals.

The reconstruction of the Pre-Roman cult house beside the Tonija tarandgrave showed that a firm surface could be created even without the use of limestone slabs, when smaller stones were used for securing its steadiness. On the other hand, it should be constantly kept in mind that as the excavated structure was not a living house, it hardly needed a smooth floor for everyday activities. The chief function of infill stones in a horizontal log construction must have been the covering of human remains - a parallel can be drawn here with Late Medieval and Modern Age churches that functioned as funeral grounds with underground burials and, in lack of constructional remains, might be misidentified during archaeological excavations as mere cemeteries. The possibility that some tarands had board floors should not be ruled out either. As conditions are rarely suitable for the preservation of timber in the archaeological record, the floor boards could have hardly left any detectable traces.

The Lepna mortuary house lacked the typical stone infill of tarand-graves and its floor was paved with limestone. This phenomenon may have been distinctive of the Migration Period, as similar floors lacking infill have also been recovered at northwestern Estonian grave sites dating back to the same era (e.g. Lagedi; Spreckelsen 1927), as well as in the Virunuka grave in Inland Estonia (Laul 2001, 68-70). In several tarand-graves, including Tõnija, limestone floors have been discovered under the infill layers. Therefore it can be assumed that if an earlier custom had demanded that human remains were to be covered with stones, then starting with the Migration Period, bones were taken to the grave sites in some sort of decayable containers that were either left on the floor or stored on shelves. It should be noted, though, that the Paju grave did still contain typical tarand-grave infill (Tamla \& Jaanits 1977), even though it was contemporaneous with the Lepna complex.

Whereas the entrances leading into the Tõnija grave were detectable, the same cannot be said of all the excavated tarand-graves. The failure to identify such 
entrance(s) may have partly been prompted by the conception that denied the existence of any entrances to tarand-graves and thus gave no reason to look for them. On the other hand, ethnographic evidence suggests that when timber decays, there may be no archaeologically demonstrable traces left of the entrance. If the threshold stone in the entryway were about the same height as other surrounding foundation stones, the doorway would not be distinguishable in the archaeological record. Relying on ethnographic parallels, we may also assume that some tarands may have been open on one side.

A Swedish archaeologist, Helena Victor, has also dealt with the issue concerning entrances. In most cases, Swedish Bronze Age cult houses with stone foundations do appear to have lacked any entrance. On the other hand, entrances can clearly be detected in the secular buildings with stone foundations in Roman and Migration Period Öland and Gotland. Among other things, Victor suggests the use of stepladderlike wooden constructions that would have been built over stone foundations. She also comes to the conclusion that the entrance to a cult house was not even supposed to be as easy and common as the access to a secular building. The Bronze Age cult houses with timber post constructions, however, usually lacked a whole wall (Victor 2002, 116-117).

The Lepna mortuary house offered another surprising ethnographic parallel. Most of the human bones and artefacts were acquired either from along the walls of the pit or the wall debris. If in the first case it could be assumed that the remains were preserved in bowls or boxes of some organic matter along the walls of the chamber, the location of the finds unearthed from the wall debris was perplexing. It seemed as if the remains had originally been placed on top of the dry-laid wall and later tumbled down with it. A matching parallel, however, was found from the ethnographic buildings of Saaremaa and Muhumaa, where the top of the limestone wall constituted a kind of a shelf under the roof that could be used as a storage space.

A similar phenomenon has been noted in some other graves as well. In Uusküla grave II, the majority of potsherds were collected from crumbled wall debris, giving the impression that the ware had originally been set upon the wall or right behind its corner. Some cremation burials were discovered from the crumbled wall between the A and B tarands that Lang has interpreted as later burials that had been deposited on top of the wall at a time when the wall's function had already changed (Lang 2000, 153, 156). Both the pottery and the burials could have been placed on the wall also in case the wall was supporting a log construction. As the Uusküla grave walls were quite wide, the builders would have had to create an empty space under the wall-beams that could have served as a repository shelf.

\section{Mortuary houses in the neighbouring countries}

The cult and/or mortuary houses known from Scandinavia belong to the Neolithic, Bronze, or Pre-Roman Iron Age. In her writings, Victor has given a good overview of the Bronze Age cult houses. According to Victor, in addition to the 
cult houses with timber post constructions, around 60 Bronze Age cult house remains built on stone foundations have been found in Sweden. The cult houses with stone foundations were usually built as narrow, elongated constructions with convex outer corners. Most of these buildings were situated in funeral grounds or beside them, but only a few had included burials (Victor 2002, $64 \mathrm{ff}$ ). Many early sacral buildings have been discovered in Denmark, including some that have contained burials. No such antiquities have been found in Norway (e.g. Seeberg 1971 and references; Victor 2002, 69-76).

The early Swedish cult houses with post constructions were definitely built of wood. In the ground plan, those structures resembled the dwellings and outhouses of that period. Even though the cultural layer tended to be very thin, they all contained hearth remains. The buildings were usually open on one side and it is in these open shelters that most of the archaeologically detectable activities were taking place (Kaliff 1997, 54-57; Victor 2002, 123 ff).

It is important to note that most of the Swedish cult houses were not burial places, though they were directly connected with them. An exception in this sense appears to have been the Klinga cult house in Östergötland that was an EastWest-directed building in the shape of an elongated rectangle consisting of two rooms. A few cremation burials were discovered in the smaller room, while the bigger room yielded bone fragments and pottery shards indicating ritual activities (Kaliff 1997, 56 and references). Although the Klinga cult house and mortuary building have been dated to the Bronze Age, the complex does offer the closest western parallel to Estonian mortuary houses. Then again, it can also be asserted that the positioning of cult houses near grave sites in the Pre-Roman Iron Age and possibly already in the Bronze Age seems to have been typical of Coastal Estonia, or at least of Saaremaa. Starting with the first centuries of our era, graves and cult houses appear to have "merged" in some places - beside carrying out rituals, the cult houses were being used as the burial places for ancestral remains.

Stone and wooden pagan-time cult structures have been found and investigated both in Latvia and Lithuania. In Lithuania, such structures date back to a long period ranging from the beginning of our era to the 15th-16th centuries. The remains generally indicate buildings with a round ground plan, but also some quadrangular examples have been found. Just as in Scandinavia, these have been solely sacral buildings and were not used as burial places. In addition to the regions populated with Baltic peoples (in the territories of present Latvia, Lithuania and parts of Russia and Poland), similar cult houses have also been discovered in northwestern Russia (e.g. Graudonis 1997; Daugudis 1995 and references). However, the existence of wooden constructions on grave sites cannot be entirely overruled in western Lithuania. This premise is supported by Rasa Banyte-Rowell's findings from the Baitai graves, where traces of wood as well as of clay jointing were discovered above the stone-enclosure (Banytè-Rowell 2001).

Somewhat surprisingly, the closest parallel to the Coastal Estonian mortuary buildings can be found at the eastern Finno-Ugric peoples, who inhabited the territory between the rivers Volga and Oka, east of Moscow, about one thousand 
kilometres away from Estonia. Though some research had also been done earlier, it was mainly in the 1990s that the local archaeologists started to stress that mortuary houses - small corner-joined horizontal log cabins, where cremated ancestral bones were stored - had been the main burial places for the local FinnoUgric population from the Pre-Roman Iron Age till the 5th-6th (maybe also 7th) centuries AD (Смирнов 1990; Башенькин 1996). Even though the distance between the Estonian coast and the Volga-Oka region does at first glance seem immense, the contacts can actually be also observed in material culture - for example, Volga-Oka style Roman Iron Age ornaments have been found in the Kõmsi single tarand-grave (and presumably also a one-time mortuary house) in western Estonia (Lõugas 1972).

The most important trade route to the Orient ran along the Volga River. It is quite possible that pre-Viking-period timber mortuary houses may also be found in the area lying between Estonia and the Volga headwaters, which used to be inhabited by Finno-Ugric peoples; unfortunately, that region has been very poorly researched. The connection is also implied by the large distribution of Iron Age chamber graves and timber constructions covered by sand barrows in that region (е.g. Кочкуркина 1981; Хвощинская 2004, 31-52).

The most renowned mortuary houses in the Volga-Oka area have been found at the Bereznyaki fortified settlement and the Savvino-Storozhevsky monastery/ fortified settlement; these antiquities belong to the Dyakovo culture that is believed to be of Finno-Ugric origin. The Bereznyaki site has been dated to the 5th-6th centuries and it was excavated in 1934. Although both of those mortuary houses were situated inside fortified settlements, modern researchers believe that the buildings were erected long after the settlements had been abandoned. The SavvinoStorozhevsky mortuary house was excavated in 1966; the antiquity presented a small house $(2 \times 1.2 \mathrm{~m})$ that had been dug into the ground to the depth of $0.5-0.6 \mathrm{~m}$. It was an elongated, North-South oriented building with a partly underground entrance situated on the southern side. A ritual hearth was located in a shallow pit in the ground just beside the entrance. Cremated bones were laid down along the walls in earthen vessels. The remains of 24 people were distinguished there, including men, women and children. The mortuary house was dated to the 3rd quarter of the 1st millennium AD (Смирнов 1990). The construction is an obvious parallel to the Lepna mortuary house in Saaremaa, though remarkably more modest in size and the amount and quality of the deposits.

Later excavations have proved that the Bereznyaki and Savvino-Storozhevsky antiquities have not been exceptions, but typical burial places of the Dyakovo culture starting with the Pre-Roman Iron Age. An interesting circumstance to be noted here is that at the Kurevanikha mortuary house (dated 3rd century BC to 1 st century AD), five putative post-holes were found (with about $20 \mathrm{~cm}$ in diameter) that had been dug into the sandy soil. The antiquity was reconstructed as a $4 \times 5.6 \mathrm{~m} \log$ house; the actual height of the building and the presence or absence of a roof remained unclear. Burials of men, women and children were found in the structure (Башенькин 1996). 
K. A. Smirnov has pointed out a number of written sources and examples from Russian folklore that have apparently been inspired by the custom of local FinnoUgric peoples to deposit the bones of dead kinsmen in small mortuary houses made of timber. The custom of bringing cremated remains to road-side huts has been described in the Tale of Bygone Years, but also in ballads. Smirnov sees a follow-up to this tradition in the character of the old hag Baba-Yaga - a clearly non-Russian female character in Russian fairy-tales - who lives in the woods in a $\log$ cabin (often depicted as "a cabin on chicken legs") full of bones. Smirnov also believes that the later chamber-grave tradition of Finno-Ugric peoples evolved from the earlier tradition of mortuary houses (Смирнов 1990).

\section{Conclusions}

Even though there is little direct evidence to prove that horizontal log houses used to stand upon the walls of Estonian tarand-graves, ample implications can still be found to support this hypothesis. In fact, it can be stated that there is no more proof to the present vision of tarand-graves as stone graves enclosed by stone walls. The finds that have not fitted the concept - like the lack of infill stones or tarand walls, the presence of flagstone floors or the walls that have crumbled both inwards and outwards of the tarand - all these circumstances have either gone unnoticed or drawn little attention, thus preventing any changes to the paradigm.

Although the similarity between the ground plans of regularly-shaped tarandgraves and building foundations has been noted by earlier researchers, the ground plans of the tarand-graves have not yet been actually compared with the house bases found from archaeological settlements. Admittedly, large-scale excavations of settlement sites in Estonia only started in the 1980s and very little was known of prehistoric buildings before that. The interpretation of tarand-graves as the foundation bases of $\log$ houses has also been hindered by the viewpoint introduced in the 1970s that the Pre-Roman Iron Age graves with irregular enclosures should be interpreted as the direct antecedents of the classical tarand-grave. It would indeed be difficult, if not impossible to imagine Pre-Roman Iron Age cairns that were wide-spread in northwestern Estonia and Saaremaa as one-time horizontal $\log$ constructions. Still, even in this case the existence of some wooden parts in the structure cannot be entirely ruled out.

Corner-joined horizontal log buildings that usually lack post-holes have been characteristic of a larger part of eastern Europe, including Estonia. It is only logical to assume that sacral buildings resembled secular structures - e.g. they were built in the corner-joining, horizontal log technique. Scandinavian parallels show that the cult houses there have also been mostly interpreted as wooden constructions, especially in the cases when post-holes have been preserved. Post-holes were also common in the Scandinavian secular architecture of the time, thus indicating the adequacy of such comparisons. The reconstruction of a horizontal log construction is much more complicated, because it does not leave archaeologically detectable 
traces, but this does not mean that such an interpretation should not be presented. Even though the goal may be unrealistic, archaeological interpretations do aim at grasping the past realities. By endowing a meaning to the preserved matter - the stone - and neglecting the possibly unpreserved - timber - we would be taking an easy shortcut and not the proper path to achieving this elusive aspiration.

\section{Acknowledgements}

The author is thankful to Triinu Mets, who translated the text into English, and to civil engineer Peeter Mägi, who helped with constructional details in the process of reconstructing the Lepna and Tõnija structures.

\section{References}

Banytė-Rowell, R. 2001. Vakarų Lietuvos kapinynų laidosenos ypatumai vėlyvuoju romėniśkuoju laikotarpiu. - Archaeologia Lithuana, 2, 29-47.

Daugudis, V. 1995. Die eisenzeitlichen Kultstätten in Litauen. - Archaeologia Baltica, 1, 121-145. Graudonis, J. 1997. Kulta vieta Vēcate. - Arheolog̣ija un etnogrāfija, XIX, 20-24.

Jonuks, T. 2003. Eesti metalliaja usundi põhijooni. Magistritöö. Manuscript in the Library of the University of Tartu. Tartu.

Jonuks, T. 2005. Archaeology of religion - possibilities and prospects. - EAA, 9: 1, 32-59.

Kaliff, A. 1997. Grav och kultplats. Eskatologiska föreställningar under yngre bronsålder och äldre järnålder i Östergötland. (Aun, 24.) Uppsala.

Kristiansen, M. S. 2002. The reconstruction of the layout and functions of a Danish farmstead. The case of farmstead no. II in Taarnby 1100-1800. - The Rural House from the Migration Period to the Oldest Still Standing Buildings. Ruralia IV, 8.-13. September 2001. Bad Bederkesa, Lower Saxony, Germany. (Památky archeologické, Supplementum 15.) Prague, 34-40.

Lang, V. 1987. Tallinna ümbruse tarandkalmed. - TATÜ, 36: 2, 190-206.

Lang, V. 1993. Kaks tarandkalmet Viimsis, Jõelähtme kihelkonnas. Tallinn.

Lang, V. 1996. Muistne Rävala. Muistised, kronoloogia ja maaviljelusliku asustuse kujunemine Loode-Eestis, eriti Pirita jõe alamjooksu piirkonnas, 1-2. (MT, 4.) Tallinn.

Lang, V. 1999. Kultuurmaastikku luues. Essee maastiku religioossest ja sümboliseeritud korraldusest. - EAA, 3: 1, 63-85.

Lang, V. 2000. Keskusest ääremaaks. Viljelusmajandusliku asustuse kujunemine ja areng VihasooPalmse piirkonnas Virumaal. (Muinasaja teadus, 7.) Tallinn.

Laul, S. 1962. Jaagupi tarandkalme Elva rajoonis. - MKA, 13-57.

Laul, S. 1990. Die Ostseefinnen und ihre Nachbarvölker (im Licht des Vergleichs ihrer vorgeschichtlichen Gräberformen). Congressus septimus internationalis fenno-ugristarum, Debrecen 27.VIII. 2.IX.1990. Sessiones sectionum. Dissertationes historica, archaeologica et anthropologica. Debrecen, 314-319.

Laul, S. 2001. Rauaaja kultuuri kujunemine Eesti kaguosas. (MT, 9; Õpetatud Eesti Seltsi kirjad, 7.) Tallinn.

Lavi, A. 1997. Asulakohad 13.-17. sajandi talurahvaehitiste ajaloo allikana. - EAA, 1, 84-144.

Lõugas, V. 1972. Lääne-Eesti rahvastiku kultuurist rooma rauaajal. - TATÜ, 21: 2, 163-175.

Lõugas, V. 1975. Tarandkalme uus rekonstruktsioonikatse. - Fenno-Ugristica, 1. TRÜ Toimetised, 344, 198-212.

Mandel, M. 2000. Poanse tarandkalmed. - Eesti Ajaloomuuseum. Töid ajaloo alalt, II. Tallinn, 89-111. 
Mägi, M. 1999. Ühe ülikupere lugu. Tuulingumäe tarandkalme Tõnijal. - Saaremaa Muuseum, kaheaastaraamat 1997-1998. Kuressaare, 3-17.

Mägi, M. 2001. Probable cult site beside the Tõnija tarand-grave on the Island of Saaremaa. - AVE, 2000, 48-55.

Mägi, M. 2004. The mortuary house at Lepna on southern Saaremaa. - AVE, 2003, 45-60.

Mägi, M. 2005. Kivikalmed ja surnumajad. Matmiskombestiku areng rauaaegsel Saaremaal. - Saaremaa Muuseum, kaheaastaraamat 2003-2004. Kuressaare, 3-34.

Mägi, M. In print, a. Changing connections, changing society: burial rites on Iron Age Saaremaa. Transformatio mundi. The Transition from the Late Migration Period to the Early Viking Age in the East Baltic. Ed. M. Bertašius.

Mägi, M. In print, b. Viking Age harbour site at Tornimäe, eastern Saaremaa. - AVE, 2004.

Mägi, M. \& Mägi, T. 2002. Archaeological fieldwork around Tõnija and Rõõsa on southern Saaremaa. - AVE, 2001, 56-64.

Mägi-Lõugas, M. 1997. Archaeological excavations at Tõnija Tuulingumäe tarand-grave, Saaremaa. - AVE, 1996. Stilus, 7, 29-39.

Mets, T. 2003. Vaimne elu: mõnda usundilistest kujutelmadest. - Eesti aastal 1200. Ed. M. Mägi. Tallinn, 69-90.

Ränk, G. 1939. Saaremaa taluehitised. Etnograafiline uurimus, I. Ehitiste üksikosad, elamu ja kõrvalhooned, mis osalt täidavad elamu ülesandeid. Tartu.

Seeberg, P. 1971. Katafalk eller dødehus. - Museerne i Viborg amt, 1, 24-27.

Spreckelsen, A. 1907. Ausgrabungen in Saage, Kirchspiel Jeglecht, Estland. - Beiträge zur Kunde Est-, Liv- und Kurlands. Bd. VI, Heft 4. Reval, 376-419.

Spreckelsen, A. 1927. Das Gräberfeld Laakt (Lagedi), Kirchspiel St. Jürgens, Harrien, Estland. (Verhandlungen der Gelehrten estn. Gesellschaft, XXIV.) Dorpat.

Šturms, E. 1938. Baltische Alkhügel. - Pirma Baltijas Vesturnieku Konference, Riga, 16.-20. VIII 1937. Riga, 116-132.

Tamla, T. \& Jaanits, K. 1977. Das Gräberfeld und der spätneolithische Siedlungsplatz von Paju. TATÜ, 26: 1, 64-71.

Tihase, K. 1974. Eesti talurahvaarhitektuur. Tallinn.

Tvauri, A. 2003. Balti arheoloogia maailmaajaloo pöörises ehk gooti teooria saatus. - EAA, 7: 1, $38-71$.

Vassar, A. 1943. Nurmsi kivikalme Eestis ja tarandkalmete areng. Manuscript in the Library of the University of Tartu. Tartu.

Vassar, A. 1966. Loode-Eesti hõimudest meie ajaarvamise I aastatuhande algupoolel. - TATÜ, 15: 2, 190-203.

Vedru, G. 2004. People on river landscapes. - EAA, 8: 2, 181-200.

Vernacular architecture $=$ Vernacular architecture at the Estonian Open-Air Museum. Catalogue, 1997. Tallinn.

Victor, H. 2002. Med graven som granne. Om bronsålderns kulthus. (Aun, 30.) Uppsala.

Башенькин А. Н. 1996. “Домик мертвых” Куреваниха-XX на р. Мологе. - Древности Русского Севера. Выпуск 1. Вологда, 141-150.

Кочкуркина С. И. 1981. Древняя Корела. Ленинград.

Ланг В. \& Лиги П. 1990. Второе селище в Удерна. - ТАТÜ, 39: 4, 433-436.

Смирнов К. А. 1990. Погребальный обряд дьяковской культуры. - Советская археология, 1990, 2, 51-61.

Тыниссон Э. 1980. Некоторые итоги изучения древнеэстонского жилища (по материалам городищ 11-13 вв.). - ТАТÜ, 29: 1, 67-78.

Хвощинская Н. В. 2004. Финны на западе новгородской земли (по материалам могильника Залахтовье). С.-Петербург.

Шмидехельм М. Х. 1955. Археологические памятники разложения родового строя на северовостоке Эстонии (V в. до н. э. - V в. н. э.). Таллин. 


\section{Marika Mägi}

\section{SURNUMAJAD RAUAAEGSES EESTIS}

\section{Resümee}

Seisukoht, et inimkätega püstitatud kultushooned polnud muistsetele eestlastele iseloomulikud, on valitsenud eesti arheoloogias niivõrd kaua, et sellest on saanud aksioom. Üsna üksmeelselt on eitatud ka tehislike kultuskohtade olemasolu, hoolimata isegi naabermaade sellelaadsetest avastustest (nt Šturms 1938; Daugudis 1995; Graudonis 1997; Kaliff 1997; Victor 2002). Tuleb siiski tõdeda, et ettekujutus spetsiaalsete kultuslike rajatiste puudumisest baseerub pikaajalisel traditsioonil rekonstrueerida eestlaste muinasusundit, tuginedes peamiselt 19. sajandil kogutud folklooriandmetele, millesse tuleks aga suhtuda ettevaatlikult (Mets 2003; Jonuks 2005). Tuleb nentida, et kultuslike ehitiste olemasolu või puudumise kohta rauaaja esimesel poolel puuduvad peale arheoloogilise allikmaterjali igasugused andmed.

Nii Valter Lang kui ka siinkirjutaja on rõhutanud muistsete kivikalmete tähtsust kultuskohtadena (Mägi-Lõugas 1997; Lang 1999). Otseselt kultushooneks tõlgendatud pronksi- või eelrooma rauaaegset rajatist, ilmselt kividest laotud vundamendile püstitatud ristpalkidest hoonet on seni kaevatud siiski vaid Saaremaal Tõnijal (Mägi 2001; Mägi \& Mägi 2002). Artiklis pole keskendutud siiski eelkirjeldatud, üksnes kultuslikele rajatistele, vaid kivikalmetele kui kultuskohtadele ja sõna otseses mõttes surnumajadele, samuti nende ehituslikele iseärasustele. Kõik siin käsitletavad matmiskohad on seni kvalifitseeritud tarandkalmeteks. Artiklis on käsitletud Ranniku-Eesti ühe- või ka mitmetarandilisi korrapärase ehitusega kalmeid, mis enamasti on dateeritavad 2.-7. sajandiga, üksikutel juhtudel aga ka eelrooma rauaajaga (joon 1). Allpool esitatud argumentatsioon ei hõlma RannikuEestile iseloomulikke nn varaseid tarandkalmeid, mis kuuluvad peamiselt eelrooma rauaaega.

\section{Tarandkalmete tõlgendused}

Termini tarandkalme tõi 1930. aastatel eesti arheoloogialeksikasse Harri Moora. Tema kaasaegne Artur Vassar käsitles tarandkalmeid kui sümboolseid surnumaju, mis oma kasutusajal olevat kujutanud endist väliselt korrapäratuid kivikünkaid. Tema arvates olevat kalmesse matmisel lisatud sinna iga uue matusega ka kive, nii et kivikiht valgunud viimaks üle tarandimüüride, kattes need täielikult ja moodustades nn äärevare (Vassar 1943, 295-296, 317 jj). Lang, kes käsitleb ebakorrapärasema ehitusega nn varaseid tarandkalmeid kui tüüpiliste tarandkalmete varasemat järku, on näinud nelinurksetes kalmepiiretes pigem keldi või balti põllusüsteemide sümboolset peegeldust (Lang 1999, 78-79; 2000, 212). Pole võimatu, et korrapärase ehitusega tüüpiliste tarandkalmete otsene seostamine eelrooma rauaaegsete varaste tarandkalmetega on ka üheks põhjuseks, miks korra- 
päraste tarandkalmete sarnasus nii arheoloogiliste ehitisjäänuste kui ka etnograafiliste ehitistega on tähelepanu alt välja jäänud. N-ö varaste tarandkalmete põhjal on raske ristpalkidest hooneid oletada ja kui klassikalised tarandkalmed olid nende otsesed järglased, ei saanud järelikult needki enesest tegelikke surnumaju kujutada.

20. sajandi teise poole teenekaimad tarandkalmete uurijad Marta Schmiedehelm ja Silvia Laul on mõlemad püsinud seisukohal, et tarandkalmete näol on tegemist kividest laotud madalate müüridega piiratud kivikalmetega, mille müüre peitis omakorda enamikul juhtudest äärevare kivikiht (nt Шмидехельм 1955; Laul 1962; 2001). Eriartikli on tarandkalmete rekonstrueerimisele pühendanud Vello Lõugas. Tema ettekujutuse kohaselt olid välismüürid tarandkalmete kasutusajal nähtavad ja neid ümbritsev äärevare kujutab enesest hiljem väljapoole varisenud müüri. Kohati kuni $75 \mathrm{~cm}$ kõrgused tarandimüürid olevat aga seestpoolt olnud siiski kividega täidetud (Lõugas 1975, joon 2).

1995.-1996. aasta kaevamised Tõnija Tuulingumäe tarandkalmel Saaremaal osutasid, et tarandite I ja II osalt raud-, osalt paekividest laotud müürid olid varisenud nii sisse- kui ka väljapoole, nende esialgne kõrgus oli olnud kuni $60 \mathrm{~cm}$. Tarandid ei saanud seega kuidagi olla seest kuni ülemise ääreni kividega täidetud (joon 3). Sellele viitab ka asjaolu, et nii Tuulingumäel kui ka üldse enamikus tarandkalmetes puudub piisav hulk kive, täitmaks tarandid üleni ja moodustamaks lisaks kalmete laele kivikuhjad. Vastupidi, tarandimüürid on paljudel juhtudel jälgitavad juba enne kaevamisele asumist, st neid moodustavad kivid ulatuvad kohati maapinnale. Sellele viitab ka rahvasuus levinud tarandkalmete sage seostamine kiriku- või kabelivaremetega (näiteid vt Lõugas 1975) - paljudel juhtudel meenutavadki kaevamata tarandkalmed vanu hoonevundamente.

\section{Tarandkalmed kui kultus- ja/või matusehooned}

Enamik Ranniku-Eesti korrapärase põhiplaaniga tarandkalmetest erineb teatud määral Sise-Eesti omadest. Näiteks pole need kuigi suured, koosnedes enamasti 3-4 tarandist. Kui üksikud erandid (nt Mäletjärve) välja jätta, on ka ühetarandilised kalmed valdavalt Ranniku-Eesti fenomen. Sise-Eesti tarandkalmetes domineerib põletusmatus, samas kui Eesti mandri rannikualadel esineb selle kõrval ka sekundaarse iseloomuga põletamata matmist, Saaremaal domineerib aga üksnes põletamata luude osalise kalmesse toomise kombestik.

Tarandkalmetes kohati esinevaid leiutühje tarandeid seostatakse enamasti võimalusega, et tarand küll rajati, kuid sinna ei jõutud mingil põhjusel matta - lähtudes seega ideest, mille kohaselt ehitas uus sugupõlv uue tarandi. Ka Tõnija Tuulingumäe idapoolseim tarand oli rooma rauaaegses kihis tühi nii leidudest kui ka luudest. Peaaegu samasugune pilt avanes läänepoolseimas tarandis (tarand IV), kus leidudest esines vaid mõnevõrra keraamikat ja enamiku leiuainesest moodustasid loomaluud, sekka üksikud inimluud. Rohkesti matuseid esines kõrvaltarandis (tarand III). Sealjuures tuleb silmas pidada, et sissepääs tarandisse III oli selgelt markeeritud (joon 4), tarandisse IV pääses aga üksnes läbi tarandi III, 
st ainus lünk tarandit IV ümbritsevas müüris oli kahe tarandi vahel (joon 5). Jääb mulje, et tegemist oli juba algselt kaheruumilise konstruktsiooniga, millest üks oli ette nähtud matusteks, teine aga põhiliselt ohverdusteks ja muudeks riitusteks. Taoline "läbikäidava toa" fenomen näib viitavat pigem kunagisele hoonele kui kiviaiaga ümbritsetud lahtisele alale.

Leidub viiteid, mis osutavad Tõnija rooma rauaaegsele tarandkalmele kui võimalikule kivivundamendile tuginenud ristpalkidest hoonele (vt ka Mägi-Lõugas 1997). Vähemalt võib nentida, et ükski fakt ei räägi selle oletuse vastu. Tõestada on seda väidet siiski raske, kuna võimalikud puukonstruktsioonid paekivide vahel ja peal ei säili, postiaukude järele puudus aga niigi kivisel pinnasel igasugune vajadus.

\section{Rahvasterännuaegne surnumaja Lepnas}

Lepna Katkuaugu nimeline kalme paiknes Tõnija kalmetest 1,2 km lõuna pool ja kujutas endast kividest ning osalt puust ehitatud hoone jäänuseid (Mägi 2004, joon 6). Konstruktsiooni keskel oli umbes $80 \mathrm{~cm}$ sügavune lohk, mida ümbritses paeplaatidest kuivmüürina laotud madal vundament mõõtmetega $8,8 \times 5,3 \mathrm{~m}$. Lohk ise oli suures osas täitunud varisenud kivide ja mullaga. Lohu põhi oli kaetud hästi säilinud paeplaatidest põrandaga. Selle kagunurgas, otse oletatava sissepääsu kõrval, leiti tuleaseme jäänused - 60-70-cm läbimõõduga söelaik põlenud kividega (joon 7).

Seesugune maasse süvendatud ehitis pidi olema olnud kaetud katusega. Etnograafilised paralleelid osutavad, et Saaremaa ilma mördita laotud kiviehitistel toetus katus palkidest raamistikule, mis oli püstitatud otse maapinnale. Kuna sellises konstruktsioonis puuduvad postiaugud, ei jää säärastest puitehitistest 1500 aasta möödudes ilmselt kuigi palju jälgi. Ainsa viitena kunagisele palkidest raamistikule leiti Lepna müürialuse loodenurgast mõned ringikujuliselt paiknevad paeplaadid, mis ilmselt olid ümbritsenud nurgaposti.

Lohu põhja-, loode- ja kirdekülge ümbritses väiksemast kiviklibust koosnev umbes 1,5 m laiune vöönd, millest saadi ka leide ja luid. Paeklibusest vööndist väljapoole jäi kaevandi põhja- ja lääneosas paeplaatide vöönd, mis koosnes sinna kas visatud või kukkunud, ilmselt mingi ehitise jaoks valitud paeplaatidest. Võimalik, et hoone katus oli olnud pealt kaetud paeplaatidega (joon 8). Hoone mahajätmise ja järkjärgulise lagunemise korral pidi suur osa katuseplaatidest libisema räästa alla, osa aga plaatidealuse plankudest katuse mädanedes hoonesse sisse kukkuma. Lagunenud paeplaate leidus tõepoolest kõikjal lohu sees pealmistes kihtides, samuti lohku ümbritseval alal. Eeldades, et lohku ja umbes 1,5 m laiust kiviklibuga kaetud ala ümbritsenud otsekui varisenud paeplaatide vöönd kujutab enesest katuselt varisenud paeplaate, tuleks oletada, et maasse süvendatud ruum moodustas vaid osa hoonest, mis tegelikult oli mõnevõrra suurem (joon 9).

Kividega kaetud katus pidi seega olema olnud längus neljas või vähemalt kolmes suunas. Tegemist oli seega kelpkatusega, mida ka näiteks Evald Tõnisson on Eesti esiajalooliste ehitiste puhul võimalikuks pidanud (Тыниссон 1980). 


\section{Võimalikud surnumajad mujal Eestis}

Tõnija Tuulingumäe rooma rauaaegsele korrapärase ehitusega tarandkalmele sarnanevad nii konstruktsiooni kui ka leiuainese poolest veel mitmed Saaremaa kalmed, näiteks Liiva-Putla, Mäla ja Võhma. Paraku puuduvad osa selliste komplekside kaevamiste kohta piisava detailsusega aruanded.

Põhja- ja eriti Loode-Eestis võiks palkidest surnumaju oletada mitmel juhul. Eelkõige tulevad siin kõne alla 1990. aastatel kaasaegsete meetoditega kaevatud Uusküla II ja Tõugu IIB üksiktarandilised kalmed, mis on dateeritud eelrooma rauaaja lõpuga. Teatud vahevormi rooma rauaaegsete tarandkalmete-surnumajade ja rahvasterännuaegsete surnumajade vahel esindab Paju kalme Lääne-Saaremaal, mida kaevati 1975. aastal. Siit leiti puidujäänused, mis ümbritsesid ristkülikukujulist kiviladet. Viimane meenutas tarandkalmete tavapärast sisetäidist ja selle kivide vahelt saadi ka enamik luid ja leide (Tamla \& Jaanits 1977). Jääb mulje, et tegemist oli tarandkalmega, mille kivimüüride asemel oli aga ristpalkidest ehitis. Samasse aega kuuluva Lepna leiukoha valgusel võib oletada, et siingi oli tegemist ristpalkidest hoone, mitte üksnes tarandikuga. Erinevalt viimasest toetusid palgid siin aga otse maapinnale, mitte kuivmüürina laotud vundamendile. Ka ei olnud Paju puhul tegemist maasse süvendatud hoonega.

Lepnaga sarnanevaid surnumaju võib oletada ka mõne Loode-Eesti rooma rauaaja ja rahvasterännuaegse üksiktarandi (nt Proosa, Lagedi XIV C ning XV B ja Lehmja-Loo I; vt Spreckelsen 1927; Lang 1996, 322-323, 240), võib-olla aga ka mõne 4.-5. (7.?) sajandi mitmetarandilise kalme puhul (nt Saha D, Viimsi I ja II; Spreckelsen 1907, 384 jj; Lang 1987; 1993; 1996, 241-246). Lagedi XIV C kalmest leiti Lepna põrandat meenutav ristkülikukujuline paeplaatidest sillutis, mis polnud aga müüriga ümbritsetud (joon 10). Samalaadse sillutise pealt kalmest XV B koos põletamata luude ning leidudega saadud söestunud ja kõdunenud puidujäänused viitavad sellele, et siingi võis olnud tegu olla ristpalkidest hoonega (Spreckelsen 1927, 51-53; joon 11). Kaheruumilist surnumaja võiks oletada ka Saha D kalme puhul (Spreckelsen 1907, 385-390; joon 12), mis dateeriti põhiliselt 4.-5. sajandisse (Lang 1996, 246).

\section{Paralleelid etnograafiliste ehitistega}

Nii eelkirjeldatud ehituslike detailide kui ka tarandkalmete põhiplaani osas üldisemalt võib tuua rohkesti paralleele hoopis hilisemast ajast pärinevate etnograafiliste hoonetega, samuti asulakohtade arheoloogilistel kaevamistel paljandunud hoonejäänustega. Siinkohal tuleb meeles pidada, et surnumaju ei saa mingil juhul otseselt eluhoonetega võrrelda. Näiteks puudus surnumajades igasugune vajadus kütmise järele, nende ehitusmaterjali valiku tingis tõenäoliselt eeskätt atraktiivsus, mitte soojapidavus või muud funktsionaalsed aspektid jne. Etnograafilises materjalis võimaldavad 19.-20. sajandi talupojaarhitektuuri abihooned sageli lähemaid paralleele arheoloogilistele surnumajadele kui tollased eluhooned. 
Lähima etnograafilise paralleeli tarandkalmete põhiplaanile pakuvadki aidad, kus kambrid on ehitatud reas üksteise kõrvale (nt Ränk 1939, 313-324, joon 13). Sissepääsud aitadesse asusid enamasti ühe külje peal reas; võis leiduda ka vahelikke, kus esikülg puudus, samuti oli vahel võimalik mõnda kambrisse siseneda vaid läbi eelmise. Juhul kui palkhoonete all oli kasutatud kivivundamenti, võis seegi olla katkendlik, st mõne seina all oli see olemas, mõne all aga mitte. Ranniku-Eestis, kus leidus õhukest paasi, polnud sugugi haruldane ka võimalus, et hoone mõned seinad olid täies ulatuses laotud kuivmüürina paeplaatidest, samas kui kõrvalseinal ei pruukinud olla palkide alla isegi kivivundamenti laotud.

Üsna sarnaseid katkendlikke kivivundamente on leitud asulakohtade arheoloogilistel kaevamistel (Lavi 1997; vt ka artikkel käesolevas numbris; joon 14). Ka tarandkalmete kaevamisel on tihtipeale osa tarandimüüre leitud puudu olevat. Seda nähtust on reeglina seletatud kalme lõhkumisega (nt Laul 1962, 16) või lähemalt selgitamata lihtsalt "mittesäilimisena" (nt Saha D kalme, Jäbara B kalme, Ojaveski kalme; Spreckelsen 1907, 385-386; Шмидехельм 1955, tahv VII, joon 35). Mõne kalme puhul on selgepiiriliste paekividest vundamentide asemel leitud ebakorrapäraseid paeplaatide vööndeid, mida on samuti seletatud halva säilivusega (nt Pada tarandkalme, Шмидехельм 1955, tahv X). Sellised vööndid sarnanevad pigem mõne ristpalkhoone seina alla topitud või laotud korrapäratutele kivivöönditele.

Lepna surnumaja osas võib tõmmata paralleele ka Ranniku-Eesti etnograafiliste eluhoonete põhiplaaniga, eriti kui oletada, et maasse süvendatud osa moodustas vaid keskse ruumi kogu ehitisest (Ränk 1939, 108 jj; Tihase 1974, 133 jj, joon 15). Ka Sise-Eesti tarandkalmete müürid osutavad, et osa tarandeist on vahel asunud just nagu suuremate tarandite sees (vrd nt Sadrametsa kalme, Virunuka kalme; Laul 2001, joon 7, 23). Arheoloogilised kaevamised asulakohtadel paljandavad sarnase pildi: mitmel juhul on keskne ruum ja selle kivivundament ümbritsetud veel täiendava kivivundamendiga (nt Lavi 1997, joon 16).

Lepna maasse süvendatud hoone, resp hooneosa meenutab ehituslikes üksikasjades väga nii arheoloogiliselt kui ka etnograafiliselt tuntud maasse süvendatud hooneid. Arheoloogilistel kaevamistel on neid enamasti interpreteeritud kui suvekööke (Lavi 1997, vt ka artikkel käesolevas kogumikus).

Keskset ruumi ümbritsenud kambrid olid etnograafilistes eluhoonetes sageli kasutusel panipaigana, vahel aga tõenäoliselt ka suvise eluruumina. Need olid 1,5-3 m laiused koridorilaadsed kütmata ruumid, vahel liigendatud eri osadeks (Lavi 1997, 117). Kitsaid pikergusi, vahel kõigest meetrilaiusi panipaiku on tuvastatud ka arheoloogiliste hoonejäänuste kõrval (nt Uderna III suitsutoaase; Ланг \& Лиги 1990, tahv XXI, 1). Tarandkalmetes on kitsad pikergused tarandid võrdlemisi levinud (nt Toila kalme, Uusküla II kalme, Virunuka kalme; Шмидехельм 1955, tahv III; Lang 2000, joon 6; Laul 2001, joon 23).

Tõnija tarandkalme äärevare koosnes spetsiaalselt valitud paeklibust. Tekkis oletus, et äärevare klibu võis ümbritseda tarandimüüre ka funktsionaalsetel - vältimaks näiteks pinnase mudastumist - või ka lihtsalt esteetilistel kaalutlustel. Äärevare iseenesest oli siiski samuti sakraalne ala, millele viitavad sealt saadud inimluud ja leiud. 
Kivikalmete äärevarele vägagi sarnanevat paeklibust vööndit hoonepõhja ümber on täheldatud näiteks Varbolas (Тыниссон 1980, joon 4), aga ka näiteks Saaremaa viikingiaegsetel sadamakohtadel (Mägi in print, b). Sageli avastatakse arheoloogilistel asulakohtadel ka hoonepõhjadest väljapoole ulatuvaid, umbes meetrilaiusi kasutatud kerisekivide vööndeid (nt Olustvere asula). Kasutatud kerisekive kuhjati maja seinte vastu ilmselt majaümbruse sillutamise eesmärgil (Lavi 1997, 90; vt ka artikkel käesolevas kogumikus).

Olulisim konstruktsiooniline erinevus arheoloogiliste ning etnograafiliste hoonepõhjade ja tarandkalmete vahel on täidisekivide esinemine tarandkalmetes (joon 17). Eluhoonetes olid ilmselt kõige laialdasemalt kasutusel muldpõrandad, vahel ka paekividest laotud või savist ja lubjast tambitud põrandad, kuid hiljemalt hilisrauaaegsetes hoonetes kindlasti ka laudpõrandad (Ränk 1939, 68-72; Тыниссон 1980, 70; Lavi 1997, 104-106). Hilisemal ajal aitades kasutatud laudpõrandad olid enamasti alt tühjad, kuid vahel on põrandaalust ala kasutatud ka panipaigana, millesse pääses põrandalaudade ülestõstmisel (Ränk 1939, 316-317).

Leidude ja luude kohatine paiknemine kobaratena Tõnija tarandkalmes võimaldas oletada, et uue matuse - purustatud põletamata luude ja matusepanuste toomisel kalmesse eemaldati mõned täidisekivid, asetati luud ning asjad tekkinud tühikusse ja kaeti see pealt taas kividega. Oluline on siinjuures silmas pidada, et rooma rauaaegsetest tüüpilistest tarandkalmetest pole kunagi leitud terveid laipu. Uue matuse kalmesse, resp surnumajja, sängitamiseks ei vajatud seega kuigi palju ruumi. Sisetäidisekivide peamiseks funktsiooniks oli ilmselt surnute jäänuste katmine - paralleeli võiks siinkohal tuua hiliskeskaegsete ja uusaegsete kirikutega, mille põrandaalust ala võidaks hoonejäänuste puudumisel lihtsalt kalmistuks pidada. Lisaks ei saa välistada, et mõne tarandi põrand on sarnaselt eluhoonetele võinud olla pealt kaetud laudadega.

Lepna surnumajas puudus enamikule tarandkalmetest tüüpiline sisetäidis ja põrand oli sillutatud paeplaatidega. Ilmselt on selline nähtus iseloomulik rahvasterännuajale, kuna sarnaseid, ilma sisetäidisekivideta põrandaid on avastatud ka Loode-Eesti samaaegsetes kalmetes (nt Lagedi; Spreckelsen 1927), samuti puudus sisetäidis näiteks osas Virunuka II kalmes Sise-Eestis (Laul 2001, 68-70). Võib oletada, et kui varasem kombestik nägi ette surnute jäänuste katmise kividega, siis rahvasterännuajal hakati luid kalmesse tooma kõdunevast materjalist nõudes, mis asetati lihtsalt põrandale või mingisugustele riiulitele. Samas tuleb nentida, et Lepna kaasaegses Paju kalmes oli veel tegemist tarandkalmetele tüüpilise sisetäidisekihiga (Tamla \& Jaanits 1977).

\section{Surnumajad naabermaades}

Skandinaaviast teada olevad kultushooned ja/või surnumajad kuuluvad neoliitikumi, pronksiaega või eelrooma rauaaega. Pronksiaegsetest kultushoonetest on hea ülevaate andnud Helena Victor. Tema andmetel on ainuüksi pronksiaegseid kivivundamendiga kultushooneid Rootsis teada 60 ringis, lisaks postkonstruktsiooniga hooneid. Sealsed kivivundamendiga kultushooned olid enamasti kitsa 
pikerguse siseruumiga konstruktsioonid, mille välimised nurgad olid reeglina kumerad. Enamik sellistest hoonetest asus kalmistuil või nende lähikonnas, kuid matuseid on neist avastatud vaid üksikutes (Victor 2002, 64 jj). Rohkesti varaseid kultushooneid on leitud Taanist, sealhulgas mõned neist ka matustega. Norras näivad sellised muistised puuduvat (nt Seeberg 1971 ja seal viidatud kirjandus; Victor 2002, 69-76).

Oluline on märkida, et enamiku Rootsi kultushoonete puhul ei ole tegemist otseste matmiskohtadega, vaid nendega vahetult seotud ehitistega. Samas võib väita, et eelrooma rauaajal ja võib-olla juba ka pronksiajal olid otse kalmete kõrval asunud eraldi kultushooned iseloomulikud ka Ranniku-Eestile või vähemalt Saaremaale. Alates meie ajaarvamise esimestest sajanditest on kalmed ja kultushooned kohati "kokku kasvanud" - lisaks rituaalide läbiviimisele sängitati nüüd kultushoonete põranda alla ka esivanemate luud.

Lätis ja Leedus on paganlikke kivist ja puust kultushooneid teada ja kaevatud juba pikka aega. Leedus kuuluvad sellised kultushooned pikka perioodi alates ajaarvamise vahetusest kuni 15.-16. sajandini. Enamikul juhtudest on tegu ümmarguse põhiplaaniga ehitistega, kuid leidub ka nelinurkseid (nt Graudonis 1997; Daugudis 1995 ja seal viidatud kirjandus). Pole võimatu, et Lääne-Leedus on puidust ehitisi olnud ka matmiskohtade peal. Sellele viitavad näiteks Rasa BanytèRowelli uurimused Baitai kalmel, kus kivipiirdega kalmekonstruktsiooni pealt leiti puidujäänuseid ja savitihendeid (Banytè-Rowell 2001).

Kõige selgepiirilisema paralleeli Ranniku-Eesti surnumajadele võib mõneti üllatuslikult leida idapoolsete soomeugrilaste juurest, Eestist umbes tuhande kilomeetri kauguselt Volga ja Okaa jõe vaheliselt alalt. Kuigi üksikuid vastavaid kaevamisi oli seal läbi viidud juba varem, on alates 1990. aastatest hakanud kohalikud arheoloogid rõhutama, et surnumajad - väikesed ristpalkidest hütid, kuhu koguti esivanemate põletatud luud - olid sealsete soomeugrilaste põhilised matmispaigad alates eelrooma rauaajast kuni meie ajaarvamise 5.-6., võib-olla ka 7. sajandini välja (Смирнов 1990; Башенькин 1996). Pole võimatu, et viikingiajast varasemaid palkidest surnumaju leidub ka Eesti ja Volga ülemjooksu vahelisel, tollal soomeugrilastega asustatud alal, sealses piirkonnas on aga varasemaid muistiseid üldse äärmiselt vähe uuritud. Teatud mõttes viitab sellele siiski rauaaja lõpu kamberhaudade ja palkidest, kuid liivakääpaga kaetud kalmekonstruktsioonide laialdane levik neis piirkonnis (nt Кочкуркина 1981; Хвощинская 2004, 31-52).

Tuntuimad Volga-Okaa vahelise ala surnumajad on leitud Bereznjakis ja Savvino-Storoževskis. Neist viimane kaevati välja 1966. aastal. See kujutas enesest 0,5-0,6 m ulatuses maasse süvendatud väikest hoonet mõõtmetega $2 \times 1,2 \mathrm{~m}$. Hoone oli põhja-lõunasuunaliselt pikergune, selle osalt maasse süvendatud sissepääs paiknes lõunaküljel. Sissepääsu kõrval põrandal asetses madalas lohus rituaalne tulease. Põletatud luud olid paigutatud savipottidesse piki hoone seinu. Tuvastati vähemalt 24 surnu jäänused. Surnumaja dateeriti meie ajaarvamise I aastatuhande 3. veerandiga (Смирнов 1990).

Hilisemad kaevamised on osutanud, et Bereznjaki ja Savvino-Storoževski muistised pole erandid, vaid Djakovo kultuurile juba alates eelrooma rauaajast ise- 
loomulikud matmiskohad. Huvitav on sealjuures märkida, et näiteks 3. sajandist eKr kuni 1. sajandini pKr dateeritud Kurevanihha surnumajas avastati hoone alal 5 liivasesse pinnasesse süvendatud paarikümnesentimeetrise läbimõõduga arvatavat postiauku. Muistis rekonstrueeriti kui palkhoone mõõtmetega $4 \times 5,6 \mathrm{~m}$; selle kõrgus ja katuse olemasolu või puudumine jäid paraku ebaselgeks. Maetud oli surnumajja nii mehi, naisi kui ka lapsi (Башенькин 1996).

K. A. Smirnov on osutanud tervele reale kirjalikele allikatele ja märkustele vene folklooris, mis on ilmselt inspireeritud soome-ugri algrahvastikule omasest kombest koguda surnud sugulaste luud eraldi seisvatesse väikestesse palkidest surnumajadesse. Sama kombe järelkaja näeb Smirnov ka vene muinasjuttudes Baaba-Jagaast, kes elab metsas palkidest (tihti millegipärast kanajalgadel) onnis, mis on täis konte (Смирнов 1990).

\section{Kokkuvõte}

Kuigi enamikul juhtudest puudub otsene tõestus ristpalkidest konstruktsiooni kunagisest olemasolust Eesti tarandkalmete müüride peal, leidub selle väite toetuseks siiski küllaga viiteid. Tegelikult võib nentida, et sama vähetõestatuks võib lugeda senist visiooni tarandkalmetest kui üksnes kivimüüridega ümbritsetud kivikalmetest. Kuigi korrapärase põhiplaaniga tarandkalmete sarnasust hoonete vundamendiga on täheldanud mitmed varasemadki uurijad, pole tarandkalmete põhiplaane seni siiski arheoloogiliste asulakohtade hoonepõhjaga otseselt võrreldud. Tõsi, arheoloogilised suurkaevamised asulakohtadel said Eestis alguse alles 1980. aastatel ja varasem teave meie arheoloogilistest ehitistest oli võrdlemisi napp. Tarandkalmete tõlgendamist ristpalkidest ehitistena on kahtlemata takistanud ka alates 1970. aastatest käibele tulnud seisukoht, mis peab eelrooma rauaaegseid ebakorrapäraste tarandikega kalmeid tüüpiliste tarandkalmete otsesteks eellasteks. Eriti Saaremaal ja Loode-Eestis levinud eelrooma rauaaegseid kivikalmeid oleks tõepoolest raske või lausa võimatu ristpalkhoonetena ette kujutada. Pole siiski välistatud, et nendegi konstruktsioon võis osaliselt puidust olla.

Suurele osale Ida-Euroopast, sealhulgas Eestile, on olnud iseloomulikud ristpalkidest ehitised, mille konstruktsioonis esineb postiauke vaid harva. On seega igati loogiline oletada, et ka meie võimalikud sakraalhooned jäljendasid igapäevaseid ehitisi, st olid püstitatud ristpalktehnikas. Mõistagi on enamasti arheoloogilisi jälgi mitte jätva ristpalkehitise rekonstrueerimine muistise osana tunduvalt problemaatilisem, mis aga ei tähenda, et tõlgenduse peaks esitamata jätma. Olgugi eesmärk mõneti ebareaalne, püüeldakse arheoloogilises interpretatsioonis ikkagi kunagise tegeliku olukorra mõistmisele. Andes tähenduse vaid säilinule, s.o kivile, ja jättes kõrvale võimaliku mittesäilinu, s.o puidu, valiksime lihtsaima, kuid kindlasti mitte tõepäraseima tee. 